DEMOGRAPHIC RESEARCH

VOLUME 40, ARTICLE 50, PAGES 1455-1500 PUBLISHED 4 JUNE 2019

https:/www.demographic-research.org/Volumes/Vol40/50/

DOI: 10.4054/DemRes.2019.40.50

Research Article

A new family equilibrium?

Changing dynamics between the gender division of labor and fertility in Great Britain, 1991-2017

\title{
Muzhi Zhou
}

\section{Man-Yee Kan}

(C) 2019 Muzhi Zhou \& Man-Yee Kan.

This open-access work is published under the terms of the Creative Commons Attribution 3.0 Germany (CC BY 3.0 DE), which permits use, reproduction, and distribution in any medium, provided the original author(s) and source are given credit.

See https://creativecommons.org/licenses/by/3.0/de/legalcode. 


\section{Contents}

1 Introduction 1456

2 Division of labor in a partnership 1459

$3 \quad$ Division of labor and fertility 1460

3.1 The specialization family model and fertility 1461

3.2 The egalitarian family model and fertility 1461

4 Changing contexts, changing relationships 1463

$5 \quad$ Data and method 1465

$\begin{array}{lll}5.1 & \text { Data and sample } & 1465\end{array}$

$\begin{array}{lll}5.2 & \text { Measures } & 1466\end{array}$

$\begin{array}{ll}\text { 5.2.1 Division of labor indicators } & 1467\end{array}$

$\begin{array}{lll}\text { 5.2.2 Parenthood status } & 1468\end{array}$

$\begin{array}{lll}\text { 5.2.3 Periods } & 1469\end{array}$

$\begin{array}{lll}5.2 .4 & \text { Other variables } & 1469\end{array}$

$\begin{array}{lll}5.3 & 1470\end{array}$

6 Results 1473

6.1 Descriptive statistics of the sample 1473

6.2 Five division of labor types 1475

6.3 The effect of the division of labor on fertility 1480

6.4 The effect of parenthood on the division of labor 1483

$\begin{array}{lll}7 & \text { Discussion and conclusion } & 1485\end{array}$

$8 \quad$ Acknowledgements 1488

References 1489

$\begin{array}{ll}\text { Appendix } & 1497\end{array}$ 


\title{
A new family equilibrium? \\ Changing dynamics between the gender division of labor and fertility in Great Britain, 1991-2017
}

\author{
Muzhi Zhou ${ }^{1}$ \\ Man-Yee Kan'
}

\begin{abstract}

\section{BACKGROUND}

There has recently been a heated debate about the relationship between gender equality and fertility. The macro-level relationship between female labor force participation and fertility has changed from negative to positive. At the micro level, a traditional gender role setting between spouses is still largely considered to be conducive to fertility.
\end{abstract}

\section{OBJECTIVE}

How has the relationship between the couple-level gender division of labor and fertility changed over the last 26 years in Great Britain?

\section{METHODS}

Data is from the harmonized Understanding Society and the British Household Panel Study. We first identify different levels of traditionalism in the division of labor by using latent class analysis. We then employ couple-level fixed-effect logistic regressions to analyze the reciprocal relationship between the gender division of labor and fertility.

\section{RESULTS}

From 1991 to 2017, the positive, reciprocal association between the traditional division of labor and fertility has been significantly weakening over time. Couples are less likely to adopt the male-breadwinner model when they have more children, and couples who adopt the male-breadwinner model are no longer more likely to have a new child from 2009 onward.

\section{CONTRIBUTION}

We take both spouses' market work and domestic work and their combinations into account to measure the gender division of labor. This measurement and the use of

\footnotetext{
${ }^{1}$ University of Oxford, UK. Email: muzhi.zhou@sant.ox.ac.uk.

${ }^{2}$ University of Oxford, UK.
} 
fixed-effect regressions enable a comprehensive and rigorous evaluation of the microlevel relationship between the division of labor and fertility. The time-varying association between the gendered division of labor and fertility provides important evidence of a changing family equilibrium in Britain. Egalitarian gender roles within a family are no longer a barrier to fertility.

\section{Introduction}

The reversed relationship between female labor force participation rates and fertility levels has ignited a heated debate about the changing equilibrium between gender inequality and family formation. Between the 1960s and the mid-1990s, fertility levels have fallen in almost all industrialized countries and reached low or extremely low levels. ${ }^{3}$ Improvements in gender equality, represented by women's increased educational attainment, rising economic autonomy, and strive for self-fulfillment outside the family, were believed to be a critical inhibitor to family formation according to the New Home Economics model and the Second Demographic Transition framework (Becker 1976, 1981; Lesthaeghe and Meekers 1987; Van De Kaa 1987). However, since the beginning of the $21^{\text {st }}$ century, the total fertility rates have stopped declining and even started to increase in many OECD countries, including the United Kingdom (Figure 1), despite the continual growth in female labor force participation rates (OECD 2017; Rindfuss, Choe, and Brauner-Otto 2016). Since then, many studies have found a positive relationship between female labor force participation rates and fertility levels, especially among the Northern European and English-speaking countries and France (Luci-Greulich and Thévenon 2014; Siegel 2017). Meanwhile, the gender gap in domestic work time continues shrinking, reflecting a slow convergence of women and men's roles even in the private sphere (Altintas and Sullivan 2016; Kan, Sullivan, and Gershuny 2011).

\footnotetext{
${ }^{3}$ Low fertility levels refer to a total fertility rate below the replacement level of 2.1 children per woman.
} 
Figure 1: Total fertility rate and female labor force participation rate in the United Kingdom

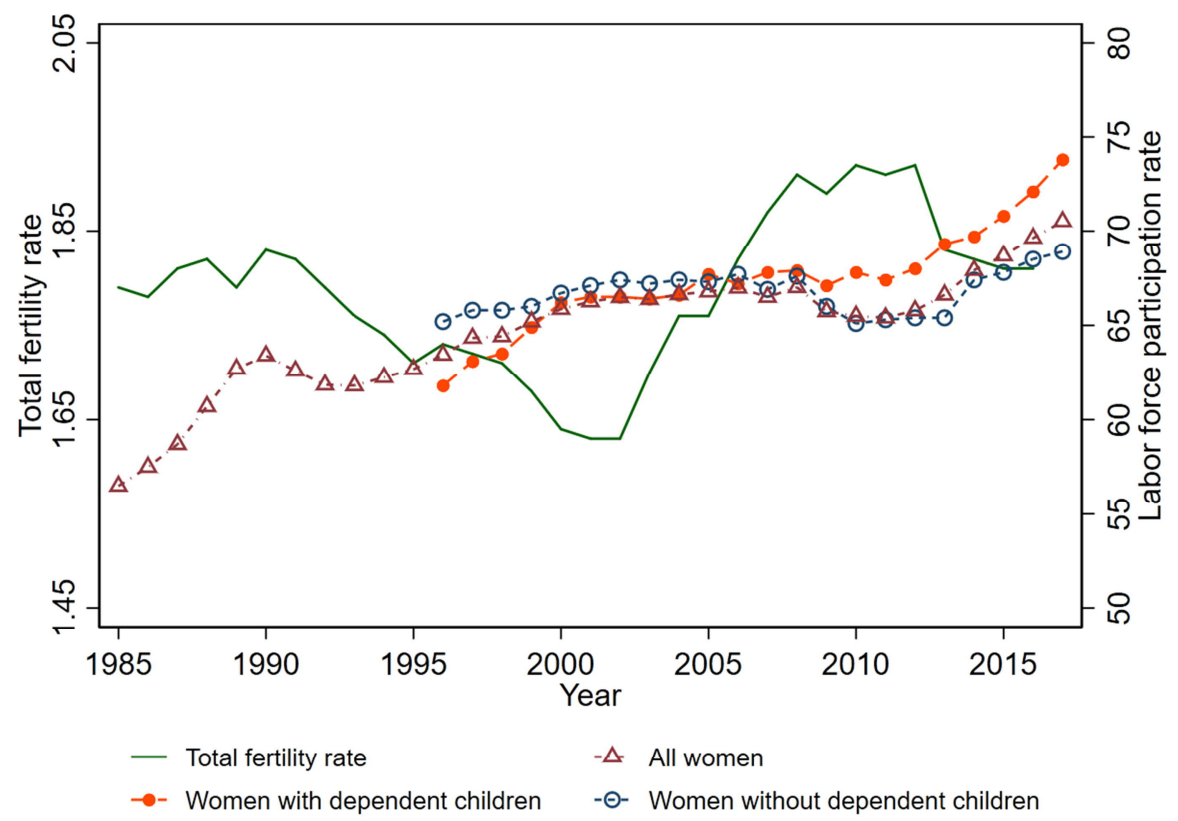

Source: Office for National Statistics.

Inspired by those changes, scholars have proposed a new relationship between gender equality and family formation. They argue that the positive association between a traditional gender role setting and fertility is likely to diminish as the gender revolution progresses. Based on the Gender Revolution framework, when women and men's roles continue to converge, eventually there will be a new family equilibrium where an egalitarian family model can even promote fertility (Esping-Andersen 2016; Esping-Andersen and Billari 2015; Goldscheider, Bernhardt, and Lappegård 2015).

Nevertheless, evidence that supports this prediction has been limited or mixed. First, many findings remain confined at macro-level cross-country analyses, and discussions have largely turned to cross-cultural variations (e.g., Arpino, EspingAndersen, and Pessin 2015; Brinton and Lee 2016; de Laat and Sevilla-Sanz 2011; Esping-Andersen et al. 2013). In addition, cross-country and cross-sectional analyses are subject to the risk of spurious findings, and analyses of changes within countries over time are necessary (Kolk 2019). Second, micro-level empirical studies usually use 
the division of housework per se to represent the level of gender equality within couples and to predict fertility (e.g., Cooke 2009; Schober 2013a). Findings are mixed and inconclusive, leading to a question of whether fertility decisions are dependent on the gendered division of labor.

We ask whether the micro-level relationship between gender equality and fertility has changed in the past few decades. In other words, we would like to know how the macro-level societal context, which has changed over time, could moderate the microlevel relationship between gender equality and fertility. Gender inequality has many dimensions. One of the most important ways that gender roles are enacted is through the division of household labor among heterosexual couples. In particular, the division of labor exhibits the couples' actual gender practices in the public and private spheres. In this paper, we use the couple-level gendered division of labor to represent the gender (in)equality level at a micro-level.

We adopt a comprehensive couple-level analysis and consider how fertility behavior is associated with the division of market labor, the division of domestic labor, and the combinations of the two spheres between spouses. This holistic couple-level approach differs from earlier studies. Past studies either make within-gender comparisons by separately analyzing women's or men's behaviors during the transition into parenthood (e.g., Kühhirt 2012; Schober 2013b), or they only attempt to predict the likelihood of having a child using the couples' employment status match (e.g., Baizán 2007) or the division of domestic labor additively (e.g., Dommermuth, HohmannMarriott, and Lappegård 2015; Neyer, Lappegård, and Vignoli 2013; Schober 2013a). These studies provide important insights to the relationship between gender inequality and parenthood, but they tend to neglect that the birth of a child was often a couple's joint decision or ignore that people's behaviors in both the public and the private spheres can be jointly influential to fertility decisions. It is also questionable that whether a couples' gender equality level could be correctly reflected through a single indicator when combinations of the two spheres offer an important dimension of gender equality. We will provide more discussions in the following sections. Most importantly, no research has examined how the relationship between the couple-level division of labor and fertility behaviors might have changed from the 2000s, despite the reverse of the macro-level relationship between gender equality and fertility and the new predictions based on the Gender Revolution framework. This study will fill this gap in the research agenda.

Analyzing how the relationship between gender equality and fertility evolves over time is important. The time-varying pattern provides novel insights into competing theories that guide people's family formation behaviors. For instance, while the traditional gender division of labor is expected to be positively correlated with childbearing and childrearing through specialization, an egalitarian family with dual 
earners is regarded to enjoy higher marital equality and to be more capable of affording the long-term cost of childrearing. By validating the applicability of these distinct family models along with the changing societal contexts, this time-varying relationship between the division of labor and fertility can provide valuable evidence about the existence of the new family equilibrium at a micro-level, thereby informing the stage and process of the gender revolution.

We use long-term harmonized panel data from the British Household Panel Study and the Understanding Society (also known as the UK Household Longitudinal Study [UKHLS]) to document a time-varying relationship between the gender division of labor and fertility. The classification of division of labor is achieved by the Latent Class Analysis, including information about how spouses (married and cohabiting partners) allocate market and domestic labor between them. We examine the effect of the division of labor on the birth of a child, as well as the effect of childrearing on the division of labor, by using fixed-effect models. We document changes in this reciprocal relationship from 1991 to 2017 and take account of potential selection due to couples' unobserved time-constant characteristics. This approach enables a rigorous evaluation of how micro-level family dynamics between gender inequality and fertility evolve with the changing social context over time.

\section{Division of labor in a partnership}

We first illustrate how labor, work, tasks, or responsibilities can be divided between spouses. Two theories have pointed out the determining role of economic resources. First, the specialization perspective suggests that the allocation of effort to market labor or domestic labor between spouses depends on their economic comparative advantages (Becker 1981, 1985). Within a family, the spouse who earns higher wages (usually the man) would take primary responsibility for paid labor, and the other (usually the wife) is primarily responsible for childcare and housework.

Alternatively, the intrahousehold bargaining perspective argues that spouses allocate resources by bargaining with each other (Lundberg and Pollak 1993; Manser and Brown 1980). The one who controls more resources (usually the man), particularly economic resources, is better able to negotiate his or her preferred outcomes (e.g., minimizing own housework time), and thus the undesirable responsibilities are allocated to the one with fewer resources. These two perspectives highlight the significance of the division of market labor in determining the overall patterns of the division of labor.

Although the above two perspectives both indicate that one's larger share of market labor is usually accompanied with his/her smaller share of domestic labor 
(Evertsson and Nermo 2007; Sullivan and Gershuny 2016), these two theories do not give details on the level of the match between the two spheres. The division of labor in the public sphere and that in the private sphere are matched in various ways, which also provides indispensable information on the level of gender equality among couples. For example, if the husband contributes $80 \%$ of the household income, does he contribute $0 \%, 20 \%$, or even $40 \%$ of domestic labor? The division of labor is less traditional if he shoulders a larger share of the domestic burden. Similarly, among dual-earner couples who have similar market labor arrangements, those with a wife doing most of the housework are regarded to be more traditional than those with a more even share of domestic labor (Hall and MacDermid 2009; Kitterød and Lappegård 2012). A more extreme example is that it is questionable to conclude that a dual-earner couple with a wife doing $60 \%$ of housework is more egalitarian than those with a part-time working wife sharing the same amount of housework. In this case, the wife in the latter setting shows stronger bargaining power than the one in the earlier setting. Accordingly, a single indicator could not accurately represent gender relations among couples. To determine the level of traditionalism in the division of labor, it is important to simultaneously consider the division of both market and domestic labor and how the two are combined.

Accordingly, we classify different levels of traditionalism in the division of labor based on three elements: the division of market labor, the division of domestic labor, and the match between the two spheres. Specifically, the most traditional division of labor type should reflect the wife and husband's most traditional gender practices in both spheres, and vice versa for the least traditional division of labor type. In between them, there are those who follow traditional gender roles in either the public or the private spheres, and there is also an egalitarian division of labor type, where a genderequal division of both market and domestic labor is observed.

\section{Division of labor and fertility}

Parenthood influences women and men in different ways and derives a gender-specific cost, which would reciprocally influence the fertility decision for couples with different levels of traditionalism in the division of labor. In this section, we first explain why parenthood influences women and men differently so that specialization is conducive to childbearing and childrearing. We then introduce the economic uncertainty and the gender equity perspectives to see how an egalitarian family model could overcome a traditional one in promoting fertility. 


\subsection{The specialization family model and fertility}

Given the persistent gender inequality in both the public and private spheres, the cost of parenthood is gendered. Childrearing has a traditionalizing effect on the gender division of labor based on the specialization and bargaining perspectives, especially when the husband has the comparative advantage in paid employment or more economic resources than does the wife, which is more likely nowadays. Accordingly, the new childcare and housework duties following the birth of a child are more likely to be allocated to the wife. Meanwhile, she often reduces her investment in market labor to cope with the new family responsibilities. Studies have consistently documented that, on average, women increase their housework time, reduce their employment hours, and experience a wage loss during the transition into motherhood (Gangl and Ziefle 2009; Schober 2013b). By contrast, men's behaviors are much less affected by childrearing (Argyrous, Craig, and Rahman 2016; Kan and Gershuny 2009, 2010; Killewald and García-Manglano 2016). These single-sex analyses imply that for couples, the division of labor would be more traditional after the transition to parenthood.

The traditionalizing effect of parenthood is translated into a lower opportunity cost for couples with a more traditional division of labor. The idea of the opportunity cost of childrearing was originally proposed to explain why women with greater earning power are less likely to have children (Becker 1981; Willis 1973). This economic perspective argues that women's education, income, and employment increase the opportunity cost of childrearing and suppress family formation. It implies that women's disadvantage in the public sphere or their traditional gender role is conducive to childbearing and childrearing. Empirical studies about the United Kingdom and other countries have shown that nonworking women are more likely to have children (Baizán 2007; Inanc 2015; Ukil 2015; Wood and Neels 2016). At a couple level, the cost of childrearing such as the reduction in the household income and living quality due to the wife's lowered economic activity to care for children is smaller for couples whose wife's share of income is lower. Accordingly, couples with a traditional division of labor should be more likely to have children than couples with an egalitarian division of labor, especially in societies where the gender inequality level is high and the institutional support for childcare is very limited.

\subsection{The egalitarian family model and fertility}

An alternative prediction is that the egalitarian family model, where the wife and the husband hold similar roles, is more beneficial for family formation than a specialization 
one. This prediction is derived from two perspectives. One has an economic concern, and another focuses on equity in a relationship.

First, the economic uncertainty perspective argues that a secure economic foundation is necessary for childrearing (Malthus 1803; Oppenheimer 1988). Compared to couples with a single earner, dual-earner couples have lower uncertainty regarding future household income, are more capable of affording the long-term cost of childrearing, and are thereby more likely to have more children (Jalovaara and Miettinen 2013; Lundström and Andersson 2012; Vignoli, Drefahl, and De Santis 2012). Economic uncertainties would also discourage families to maintain a long-term male-breadwinner model following the birth of a child (Langner 2015; Ruggles 2015). This economic perspective highlights the importance of women's economic resources in family formation. In a societal context where there are substantial economic uncertainties and a high level of economic autonomy of women, this perspective predicts a positive relationship between the dual-earner family model and fertility.

This perspective overlooks the fact that the division of market work between spouses and that of domestic work are associated with fertility jointly and simultaneously. From a gender equity perspective, simply a gender-equal division of market labor represented by the dual-earner couples does not necessarily benefit family formation. It argues that the combination of a wife's significant economic role and her disproportionately large share of family responsibilities lead to severe work-family conflicts, a perception of unfairness, or low satisfaction in marriage (McDonald 2000). Accordingly, this mismatch instead can deter childbearing, and it is also unpractical for childrearing. Prior studies have evaluated whether an unequal division of housework has a negative effect on fertility intentions or the likelihood of childbearing, but the findings are inconsistent or only weak associations are noted (Miettinen, Lainiala, and Rotkirch 2015; Mills et al. 2008; Neyer, Lappegård, and Vignoli 2013; Schober 2013a). A few studies focus on the impact of the mismatch or the conflicts between women's employment and family responsibilities on fertility. For example, Torr and Short (2004) analyze the effect of the division of housework on a second birth among American dual-earner couples but find a U-shaped relationship - couples where wives share housework equally or do almost the whole load are most likely to have a second birth. Cooke (2009) uses data from Italy and Spain to test the interaction effects of the husband's share of childcare and the wife's employment status. She finds out that when wives spend longer hours on market labor, the likelihood of having a second child will drop if the husband's share of childcare does not increase accordingly. This line of work shows the importance of considering the combination of paid and unpaid work among couples in the case of the birth of a second child. However, findings are mixed. It is not certain as to whether the findings could be generalized to first and other births. Furthermore, the method employed in these studies could not rule out selection bias due 
to the couples' shared long-term values or preferences about children and families, which influence both the couples' division of labor arrangement and fertility outcome. Therefore, we need better measures of the gendered division of labor and regression analyses that could minimize the confounding effects due to unmeasurable lifestyle preferences or values to tackle the predictive power of the division of labor on fertility.

Taking both aforementioned perspectives into account, only couples who have a relatively gender-equal division of labor in both the public and private spheres should be considered as a true egalitarian family model and will be more likely to have children than other division of labor types.

\section{Changing contexts, changing relationships}

The micro-level relationship between the division of labor and fertility is inevitably influenced by macro-level societal contexts, such as the gender norms, institutional settings, and the labor market condition. The 'doing gender' perspective argues that women and men internalize and perform their expected gender roles imposed by gender norms regardless of the partners' relative earning power or resources (Brines 1994; Kolpashnikova 2018; Kühhirt 2012; Stryker 1968; West and Zimmerman 1987). Gender norms assign gender-specific meanings to the roles of mothers and fathers and reward women and men differently (Fahlén 2016; Hays 1996; Kühhirt 2012). The 'good father' roles are consistent with a 'good provider model,' which rewards men's market commitment and wage earning ability (West and Zimmerman 1987). In contrast, the values and expectations of motherhood are to prioritize the needs of children, whereas the necessity to support the household financially becomes "secondary" (Garey 1999; Hays 1996; Mercer 2004). Therefore, the cost of parenthood is more gender specific when gender norms are more traditional. The positive relationship between the traditional division of labor and fertility would be particularly stronger when women and men adopt the gender-specific expectations of parents and 'do gender.'

Male-breadwinner families should still be more conducive to childrearing in the United Kingdom, where social attitudes and institutional settings largely retain the traditional gender settings. For instance, in 2012, almost $40 \%$ of British people considered it the best for young children to have mothers work part-time and fathers work full-time (Scott and Clery 2013). In 2018, over half of the public considers that mothers should take more parental leave than fathers (Taylor and Scott 2018). With respect to the institutional settings, the UK's family policy has displayed a strong preference for women's childrearing responsibilities: A maximum of 52 weeks of maternity leave is permitted, now up to 39 weeks are paid. Paid paternity leave for up to 
two weeks has been available only since 2003. Starting only in 2015, fathers and mothers can share their parental leave for children born or adopted. ${ }^{4}$ However, it is estimated that only about $2 \%$ of fathers who are eligible for shared parental leave have used it each year since its introduction. ${ }^{5}$ In addition, formal childcare services are predominantly private, inadequate, and costly (Connolly et al. 2016), posing a further barrier to the dual-earner model. In summary, both the social attitudes and the institutional setting imply that it is women's responsibility to take care of family, and alternative childcare options are often unfeasible. Compared to a gender egalitarian model, a male-breadwinner female-housekeeper model better fits the institutional setting and the socially expected roles of mothers and fathers and should be conducive for childbearing and childrearing.

Nevertheless, the relationship between the gendered division of labor and fertility may have altered with changing gender norms and institutional settings, though the gender revolution is far from completion. For example, people have increased their support for maternal employment. The proportion of people who agreed that mothers should stay at home declined from 64\% in 1989 to 33\% in 2012 (Scott and Clery 2013). The 2018 British Social Attitudes Survey shows that $72 \%$ dispute the view that a man's job is to earn money and that a woman's job is to look after the home. This number was $58 \%$ ten years ago. Therefore, women and men are less likely to specialize in partnerships by following the 'traditional' expectations.

The gender gap in earning power is also shrinking. In almost all the OECD countries, the gender gap in education has been eliminated or even reversed (OECD 2015), and the husband's economic advantage is less prominent when the wife is less likely to marry 'up' in terms of education or income (De Hauw, Grow, and Van Bavel 2017). The gender pay gap also keeps closing: It decreased from $27.5 \%$ in 1997 to $21.9 \% 2007$ and finally to $18.4 \%$ in 2017 based on median hourly earnings (Office for National Statistics 2017). In addition to these improvements in gender equality in the public sphere, the substantial economic uncertainty, exampled by the economic recession around 2010, further enhances the economic advantage of the dual-earner family model. Women's economic position has been critical when globalization has increased the rate of economic and social change, intensified competition, and increased sensitivity of domestic economy to random shocks occurring in the international market (Blossfeld et al. 2008). In summary, the differentiated earning capabilities or the gap in economic resources between spouses, upon which the

\footnotetext{
${ }_{5}^{4}$ Mothers must still take the initial two weeks after birth.

${ }^{5}$ This is based on figures from a press release of the Department for Business, Energy and Industrial Strategy, published on February 12, 2018. https://www.gov.uk/government/news/new-share-the-joycampaign-promotes-shared-parental-leave-rights-for-parents (retrieved December 11, 2018).
} 
economic specialization and bargaining theories are rested, are increasingly less likely to hold over the years.

In addition, there is more institutional support for early childcare provision to encourage more families to maintain an egalitarian model. In September 2010, for example, the Department for Education introduced 570 hours of free childcare per year for all 3- and 4-year-olds in England, as well as for 2-year-olds from disadvantaged backgrounds since 2013 (National Audit Office 2016). Women with young children have increased time availability for paid work when they could easily outsource childcare.

In summary, the societal context of substantial gender inequality, which empowers the prevalence of the specialization family model, is waning. Over the years, the cost of parenthood should be less gender specific. Against this background, we expect that the association between the traditional gender division of labor and fertility would be still positive; however, this positive association should decline over the recent years.

\section{Data and method}

\subsection{Data and sample}

We use the newly published harmonized data combining all 18 waves of the British Household Panel Survey (BHPS) and the first 8 waves of the Understanding Society panel study (also known as the UK Household Longitudinal Study [UKHLS]). ${ }^{6}$ For the first wave of the BHPS, a national representative sample of 5,500 households from Great Britain was recruited. BHPS later included extension samples in Scotland and Wales in 1999 and Northern Ireland in 2001. Building on the work of BHPS, a national representative sample of over 40,000 households was collected during 2009 and 2010 across the United Kingdom, forming the first wave of the UKHLS. The old BHPS sample was included in the UKHLS survey from wave 2 (2010/2011). In both surveys, beginning with the year of entry, household members aged 16 and older are interviewed, and the same individuals are reinterviewed in successive years. We take advantage of the length, the inclusion of new samples in UKHLS, and the consistent longitudinal and intergenerational design of both surveys to investigate the relationship between fertility and the division of labor.

We restrict the sample to those who are currently living with their married or cohabiting partners for a couple-level analysis. Samples from Northern Ireland are

\footnotetext{
${ }^{6}$ University of Essex, Institute for Social and Economic Research (2018). Understanding Society: Waves 18, 2009-2017 and Harmonized BHPS: Waves 1-18, 1991-2009: Special License Access. [data collection]. 10th Edition. UK Data Service. SN: 6931, http://doi.org/10.5255/UKDA-SN-6931-9.
} 
excluded because they are not included in the BHPS sample before 2001 and may disrupt the time trend. In each wave, we select couples where the female partner is the main respondent, aged between 20 and 44 years, and is currently living with a male partner aged between 20 and 59 years. Observations entering this sample in subsequent waves are predominantly new samples collected in BHPS or UKHLS. ${ }^{7}$ Observations in which either the wife or husband is a full-time student are dropped. The selected couples are at their prime childbearing and working age and are most likely to experience a competing demand from employment and family. We have 14,451 couples with 63,819 couple-wave records of self-interviews. ${ }^{8}$ After dropping observations with missing values, we ultimately have a sample of 12,888 couples and 60,548 couple-wave observations for cross-sectional analyses. Out of this sampling, 70.6\% of the couples have repeated observations and are used for fixed-effect regression analyses. We do not find that wave nonresponse is correlated with the division of labor or the birth of a child, and potential bias due to the selection of sample, if any, does not alter our conclusions. ${ }^{9}$

\subsection{Measures}

First, we need indicators that directly capture the couple-level division of labor in both the public and private spheres. These indicators will be included in the later latent class analysis to help generate a division of labor typology.

\footnotetext{
${ }^{7}$ For example, couples from the 1,000 low-income households are collected from 1997 to 2001 in BHPS. UKHLS included completely new samples in the first wave (2009/2010).

${ }^{8}$ The $1^{\text {st }}$ wave (1991) of the BHPS and the $3^{\text {rd }}, 5^{\text {th }}$, and $7^{\text {th }}$ waves of the UKHLS do not include questions about housework time. Notably, in the first wave of the UKHLS, the housework question was asked only of individuals interviewed between January and June 2009. All individuals in these wave were included in later regression analyses because the latent class analysis (LCA) allows missing information in the LCA indicators, and this approach could enlarge the sample size. Excluding individuals from these waves does not alter the results though.

${ }^{9} \mathrm{~A}$ variable indicating whether a respondent is observed in the following wave was included in later models. The estimates for this variable were not statistically significant. We further included more samples to check the potential sample selection bias. For example, we used Cox proportional hazard models to predict the birth of a child. We employed random effects models when analyzing the effect of childrearing on the division of labor, although the estimates differ from the fixed-effect estimates. Nonetheless, the conclusions from all models are consistent with the currently reported conclusions from the fixed-effect models.
} 


\subsubsection{Division of labor indicators}

We select (1) employment status match, (2) wife's share of income, and (3) wife's share of time spent on housework as indicators.

We first identify the employment status for the wife and the husband separately so that how the couple combine their labor market performance can be determined. Employment status for the wife is classified into three categories: full-time employment (working 30 hours or more per week), part-time employment (working fewer than 30 hours per week), and nonworking. For the husband, the categories are either full-time employment or other (part-time employment and nonworking) because only $4.4 \%$ of men in our sample are working part-time. Accordingly, there are six employment status matches between the wife and the husband.

Another division of labor indicator is the wife's share of income. It is calculated by dividing the wife's monthly personal income over the sum of the monthly personal income of both spouses. This share of income is further classified into four categories with similar numbers of observations in each category: women's share below $20 \%$, women's share of $20 \%$ to $40 \%$, women's share of $40 \%$ to $60 \%$, and women's share above $60 \%{ }^{10}$ This indicator can differentiate couples with similar employment arrangements but different earnings.

The third indicator is the division of housework. Information on housework is collected by asking, "About how many hours do you spend on housework in an average week, such as time spent cooking, cleaning, and doing the laundry?" Respondents are more likely to report routine housework time by asking questions in this way. Although the stylized or questionnaire-based estimates are less accurate compared to diary-based estimates of housework time, the main source of error for the stylized measures does not differ from that for the questionnaire-based measures, and most of the errors are random rather than systematic (Kan and Pudney 2008). Moreover, the panel nature of the surveys enables us to track changes in housework time for the same couple. Therefore, we prefer the stylized measures of housework time. Wife's share of housework is calculated by dividing the housework hours reported by the wife over the total housework hours, which is the sum of the housework hours reported by both spouses. This share of housework is further classified into four categories, with similar numbers of observations in each category: women's share below $50 \%$, women's share of $50 \%$ to $75 \%$, women's share of $75 \%$ to $90 \%$, and women's share above $90 \%$.

Division of childcare is not included because it is only available for parents with young children and is closely related to ideals of parenthood and the intergenerational transfer of human and cultural capital. Compared to the division of labor in housework,

\footnotetext{
${ }^{10} 90$ couples with the wife or the husband reporting zero or negative monthly personal income are assigned the value of $50 \%$ and grouped into the $40-60 \%$ category.
} 
which works as an indicator of the gender role settings among couples, the division of labor in childcare is less ideal. The domestic division of labor literature also treats housework and childcare as distinct categories because the micro-gender theories apply well to housework but not childcare (Sullivan 2013). Nevertheless, we have conducted alternative analyses by including childcare as an indicator, and the conclusion remains unchanged. ${ }^{11}$

The goal is to identify a couple-level division of labor type and then evaluate their relationships with the birth of a child. Earlier discussions indicate that the relationship between the division of labor and fertility is not necessarily linear. Using these categorical indicators can identify a typology of the division of labor through latent class analysis, which is useful to capture its nonlinear relationship with the birth of a child.

Next, we introduce key variables that are correlated with the couple-level division of labor and several control variables to be included in regression models.

\subsubsection{Parenthood status}

A key relationship we are interested is whether couples are more likely to have a child if they follow the male-breadwinner female-housekeeper family model. To predict the birth of a child, for each couple-wave record, parenthood status works as a dependent variable and is firstly set as zero (no change in the number of children) but is recoded to one (a new child) if, in the next couple-wave record, there is both an increase in the number of children and the age of the youngest child is younger than 4 years old. ${ }^{12}$

The second relationship we are interested in is to what extent the couples adapt a specialization model in order to care for children. When predicting the division of labor type, parenthood status works as a key independent variable and is represented by the number of children aged 15 years or younger in the household. It has three categories: zero (reference), one, and two or more. ${ }^{13}$

\footnotetext{
${ }^{11}$ We also included the division of childcare (mainly the wife, shared by both, others) as an additional indicator to construct the division of labor for parents. First, the classification of the division of labor for parents remains largely unchanged. Second, using this division of labor in regressions predicting the birth of a child generate the same conclusion. Lastly, this information about the division of childcare is not collected in four waves and for families with the youngest children older than age 12 (BHPS) or age 15 (UKHLS). Therefore, the current approach using employment, income, and housework as indicators are valid and sufficient, and it also maximizes the sample size.

${ }^{12}$ In this sample used for fixed-effect regressions in predicting birth outcome, $22.3 \%$ are followed within one year, $63.5 \%$ are followed up between one to two years, and $14.2 \%$ are followed up after two years.

${ }^{13}$ The age of the youngest child is not included to make the models easier to understand. The results thus represent a general relationship between the division of labor and the parenthood status, disregarding the age of the youngest child. Including the age of the youngest child does not alter our conclusions.
} 


\subsubsection{Periods}

The specific historical period is another important indicator because we would like to evaluate whether the above two relationships of interest vary in different periods. The year when the couple-wave observation is recorded is grouped into three categories. ${ }^{14}$ The reference group covers the period of 1991 to 2000, the second category is from 2001 to 2008, and the last category is from 2009 to 2017 (from the first wave of the UKHLS). There are similar durations in each period. This classification also differentiates and compares samples that started in BHPS and those that entered the UKHLS. This classification also separates the pre- and post-financial crisis period, which is expected to have an impact on family lives by increasing the economic uncertainties and enhancing women's economic role, as discussed earlier.

\subsubsection{Other variables}

In fixed-effect regressions, we further include marital status, which is classified as whether currently married (reference) or cohabiting. The age and its square term of both spouses are included. We also include the duration of the partnership. For cohabitating observations, it is the number of years from the year of cohabitation. For married observations, it includes the number of years of cohabitation if they marry after the same cohabitation. We also include numbers of years till the next observation in the fixed-effect models when predicting the birth of a child.

For cross-sectional analysis, we also include education, health, religiosity, race, and residence information, which are largely stable over time, as controls. Educational attainments of both spouses are coded as first degree or above, some high qualifications, and General Certificate of Secondary Education (GCSE) level or lower (reference). The health condition of both spouses is a self-rated score on a scale of 'Excellent' (reference), 'Good,' 'Fair,' and 'Poor.' Respondents' religiosity is coded as not religious (reference) if the answer is 'no religion' to the question "Do you regard yourself as belonging to any particular religion?" Respondents' race is classified as 'White' (reference), 'Black,' 'Asian,' and 'Others.' The place of residence category includes England (reference), Wales, and Scotland.

\footnotetext{
${ }^{14}$ Years of interview are treated as categorical variables in fixed-effect regressions to avoid multicollinearity with partnership duration, which is included in the models as a control variable.
} 


\subsection{Analytical strategy}

The analytical strategy contains four parts.

1. First, we use the three selected indicators to construct a holistic couple-level division of labor typology through the latent class analysis. This step would enable us to identify different division of labor types. In addition, each couple-wave record will be assigned a single measure indicating its division of labor type.

2. We then provide a detailed description of the division of labor types. We use a multinomial logistic regression model to predict the division of labor outcome with key cross-sectional predictors to provide an overall understanding of the division of labor types and how the distribution of the division of labor types may vary over time.

3. Back to the association between gender inequality and fertility, we use the division of labor type to predict a couple's fertility behaviors. Using fixedeffect logistic regressions, we test that if a couple adopts a specialization family model rather than an egalitarian one, whether the likelihood of having a child increases and whether this relationship changes in different time periods.

4. In the last step, we investigate the reversed direction of the relationship between the gender inequality and fertility. We examine that if a couple has more children, whether the division of labor type becomes more specialized and whether this traditionalizing effect of parenthood changes in different periods, using fixed-effect logistic regression.

Now we introduce each method in detail.

We first use latent class analysis (LCA) to determine the division of labor type for each couple-wave observation. LCA is a method used to cluster observations into different unmeasured classes based on their patterns of response across a set of defined indicators (Bakk, Tekle, and Vermunt 2013). It is a model-based clustering method using maximum likelihood to estimate the parameters of the distributions of classes, such as class numbers, sizes, and probabilities of the observations being members of a given class. This feature enables researchers to focus on the set of classes identified rather than consider each of the observed indicators separately or all the possible combinations of the indicators (McCutcheon 1987). In our case, there are 96 combinations of the three indicators ( 6 categories of employment match $\mathrm{x} 4$ categories of share of income x 4 categories of share of housework). It is thus extremely helpful when we would like to construct a typology of the division of labor that contains information on (1) the division of market labor, (2) the division of domestic labor, and 
(3) the interactions between (1) and (2) when it is neither realistic nor necessary to consider all the possible interactions of the indicators.

Furthermore, the outputs of LCA are several classes of the division of labor (rather than a continuous measure such as the output of factor analysis). The categorical outputs are desirable because the relationship between the division of labor and fertility is unlikely to be linear and varies across periods from the earlier theoretical discussions. Therefore, we can apply the division of labor as a categorical variable directly in later regression analyses without assuming a specific, and most likely incorrect, relationship between the division of labor and fertility.

We build a simple latent class model using only the three indicators discussed above to identify the typology of the division of labor. We select the appropriate number of latent classes with the lowest value of BIC. ${ }^{15}$ LCA also assigns each observation to the latent class with the best match based on the probability of membership into each class generated from models with the help of the Stata LCA plugin (version 1.3.2).

After we have assigned the division of labor type to each couple-wave observation, in the next part, we provide a descriptive overview of factors associated with different division of labor types. We use a multinomial logistic regression model to predict the division of labor outcome and apply population-equilibrated cross-sectional weights. ${ }^{16}$ Clustered standard errors are used because many couples are observed repeatedly.

Then we aim to establish the relationship between the different division of labor types and fertility and examine whether this relationship varies over the years. Given that our sample follows the same individuals with their matched spouses over time, we conduct couple-level fixed-effect logistic analyses in the third and fourth parts. The use of a fixed-effect model is particularly desirable because both the division of labor and fertility behaviors are expected to be strongly correlated with the couples' own gender and family values (Hakim 2000, 2003; Kaufman 2000; Zhou 2017). A fixed-effect model uses the same couple as its own control and removes confounding effects due to unobserved time-constant features that are correlated with both the dependent and independent variables, such as the couples' stable lifestyle preferences, family values, and long-term physical conditions. This approach lowers the vulnerability of our models to omitted-variable bias and creates great confidence in the robustness of the conclusions. The fixed-effect approach also lowers reporting errors that people constantly misreport their information (e.g., time on housework) due to time-constant features.

\footnotetext{
${ }^{15}$ BIC is commonly used for model comparisons. It assesses goodness of fit while penalizing additional parameters.

${ }^{16}$ The population-equilibrated weight reweights the data such that each period has the same number of observations.
} 
Using the fixed-effect model, in the third part, we evaluate whether the odds of having a child differs if a couple has different arrangements in the division of labor (e.g., job loss, promotion, house-moving, etc.). In our sample, the division of labor varies substantively for the same couple (the last sentence in Footnote 19 lists details of the time duration where the couples belong to different division of labor types). We use variables measured at different time points to infer a direction of the association. The model is as follows:

$$
\log \left(\frac{P_{i t+1}}{1-P_{i t+1}}\right)=\beta \text { Coupledom }_{i t}+\gamma \text { Period }_{i t}+\delta Z_{i t}+\theta \vartheta_{i}+\varepsilon_{i}
$$

where index it denotes couple $i$ at time point $t . P_{i t+1}$ is the probability of having a new child in the next record, at time $t+1 .{ }^{17}$ Coupledom $_{i t}$ is the division of labor type for couple $i$ at time $t$, with $\beta$ as the coefficient. Period $i t$ is the period category for couple $i$ at time $t$, with $\gamma$ as its coefficient. $Z_{i t}$ represents other time-variant control variables, such as the number of children, whether cohabiting, partnership duration, the couples' age and age squared terms, and the number of years till the next observation. $\vartheta_{i}$ is a vector of time-invariant predictors. $\varepsilon_{i}$ is the combined effects of all time-constant unobservable factors, with a fixed value for each couple.

Because fixed-effect analysis only uses within-couple variations, couples who do not have a change in outcome are not used, and $\vartheta_{i}$ and $\varepsilon_{i}$ are dropped out of the equation (Allison 2009: 29). Please refer to Note 9 in the 'Data and sample' section for a discussion about potential sample selection issues. Coefficients are estimated using conditional maximum likelihood, which is achieved by conditioning the likelihood function on the total number of birth events observed for each couple. For example, if a couple has been observed five times, the question asked in order to determine each couple's contribution to the likelihood function is the following: Given that the couple has a new child in two out of the five records, what is the probability that this event happened when it actually occurred rather than in one of the other possible pair of records (Allison 2009: 32). This model reports on whether the likelihood of having a child changes if a couple experienced a change in the division of labor type. We then interact different divisions of labor types with the period variable to examine how the association between the division of labor and fertility varies with time. In the interaction model, the main effect is the effect of the division of labor on the birth of a child in the reference period, which is 1991 to 2000. Combining the main effect and results from the interaction terms reveal the effects of the division of labor in 2001 to 2008 and in 2009 to 2017. This interaction model illustrates how the effect of the

\footnotetext{
${ }^{17}$ When predicting the birth of a child, we exclude those who are currently pregnant or have a new child within the next 12 months to minimize potential anticipation effect that couples adjust their behaviors because they are expecting an immediate arrival of a child.
} 
division of labor on the birth of a child, after considering time-constant confounders in each period, varies with time.

In the fourth analytical part, we then predict, using the same fixed-effect approach, the odds of belonging to a specific division of labor type if a couple has different numbers of children. The basic model is as follows:

$$
\log \left(\frac{P_{i t}}{1-P_{i t}}\right)=\beta \text { Parenthood }_{i t}+\gamma \text { Period }_{i t}+\delta Z_{i t}+\theta \vartheta_{i}+\varepsilon_{i},
$$

where $P_{i t}$ is the probability of falling into a specific division of labor type for couple $i$ at time $t$. Parenthood $d_{i t}$ is the number of children in the household for couple $i$ at time $t$. Period $i t$ is the period category for couple $i$ at time $t$. $Z_{i t}$ represents other time-variant control variables, including whether cohabiting, partnership duration, and the couples' age and age squared terms. $\vartheta_{i}$ and $\varepsilon_{i}$ are the same as in Equation 1. This model predicts whether a change in the number of children is associated with a change in the division of labor type. We then interact the parenthood status with the period variable to examine how the effect of parenthood on the division of labor varies in different periods.

\section{Results}

\subsection{Descriptive statistics of the sample}

Table 1 presents the weighted summary statistics of variables used for later regression analyses. In our sample, $41.8 \%$ of the couples are composed of two full-time workers. The second-largest category, accounting for $29.0 \%$, is that of couples with a part-time working wife and a full-time working husband. And $17.3 \%$ of the couples are composed of a nonworking wife and a full-time working husband. Over time, the distribution of the employment status match remains largely stable. Over half of the wives share less than $40 \%$ of income while $30 \%$ of the couples have wives who share $40 \%$ to $60 \%$ of income. The proportion of total income shared by the wife is growing. During the period from 1991 to $2000,62.6 \%$ of the wives contributed less than $40 \%$ of total income, and this number dropped to $53.3 \%$ during the period from 2009 to 2017 . More wives have become the primary income contributor (share $>60 \%$ of total income) in later periods as well. Housework remains the wife's job: Only $12.8 \%$ of the couples have wives sharing less than $50 \%$ of the housework, and more than $50 \%$ of the couples have wives doing more than $75 \%$ of the housework. Despite this overall inequality in housework share, the wife's share of housework declines over time. During the period 
Zhou \& Kan: Changing dynamics between the gender division of labor and fertility in Great Britain

from 2009 to 2017 , wives shared $50 \%$ to $75 \%$ of housework in approximately $40 \%$ of the couples, and these couples were the dominant group.

Table 1: Weighted descriptive statistics for the selected couple-wave observations

\begin{tabular}{|c|c|c|c|c|}
\hline & All & 1991 to 2000 & 2001 to 2008 & 2009 to 2017 \\
\hline \multicolumn{5}{|l|}{ Employment match } \\
\hline Women FT Working x Men FT Working & $41.8 \%$ & $40.9 \%$ & $41.7 \%$ & $42.7 \%$ \\
\hline Women FT Working x Men PT/Nonworking & $3.7 \%$ & $3.6 \%$ & $3.3 \%$ & $4.3 \%$ \\
\hline Women PT Working x Men FT Working & $29.0 \%$ & $28.1 \%$ & $31.6 \%$ & $26.9 \%$ \\
\hline Women PT Working x Men PT/Nonworking & $2.4 \%$ & $2.2 \%$ & $2.2 \%$ & $2.9 \%$ \\
\hline Women Nonworking x Men FT Working & $17.3 \%$ & $18.5 \%$ & $17.2 \%$ & $16.3 \%$ \\
\hline Women Nonworking x Men PT/Nonworking & $5.8 \%$ & $6.8 \%$ & $4.0 \%$ & $6.9 \%$ \\
\hline \multicolumn{5}{|l|}{ Women's share of income } \\
\hline$<20 \%$ & $25.3 \%$ & $30.1 \%$ & $24.5 \%$ & $21.6 \%$ \\
\hline $20 \%-40 \%$ & $32.7 \%$ & $32.5 \%$ & $33.6 \%$ & $31.7 \%$ \\
\hline $40 \%-60 \%$ & $30.0 \%$ & $28.3 \%$ & $30.1 \%$ & $31.4 \%$ \\
\hline$>60 \%$ & $12.0 \%$ & $9.1 \%$ & $11.8 \%$ & $15.3 \%$ \\
\hline \multicolumn{5}{|l|}{ Women's share of housework } \\
\hline$<50 \%$ & $12.8 \%$ & $10.5 \%$ & $12.2 \%$ & $17.9 \%$ \\
\hline $50 \%-75 \%$ & $33.8 \%$ & $31.1 \%$ & $33.2 \%$ & $39.5 \%$ \\
\hline $75 \%-90 \%$ & $28.9 \%$ & $29.4 \%$ & $29.9 \%$ & $25.9 \%$ \\
\hline$>90 \%$ & $24.6 \%$ & $29.1 \%$ & $24.7 \%$ & $16.7 \%$ \\
\hline Couples having children in household & $71.2 \%$ & $69.2 \%$ & $72.1 \%$ & $72.0 \%$ \\
\hline Number of coresiding children & $1.35(1.13)$ & $1.32(1.14)$ & $1.33(1.08)$ & $1.36(1.13)$ \\
\hline Women's age & $34.20(6.26)$ & $33.67(6.39)$ & $34.88(6.41)$ & $34.63(6.08)$ \\
\hline Men's age & $37.04(7.40)$ & $36.22(7.33)$ & $37.52(7.40)$ & $37.62(7.32)$ \\
\hline Cohabitation & $23.8 \%$ & $16.9 \%$ & $24.6 \%$ & $29.7 \%$ \\
\hline Partnership duration if partnered (years) & $9.24(6.24)$ & $9.64(6.60)$ & $9.84(5.78)$ & $10.07(6.14)$ \\
\hline \multicolumn{5}{|l|}{ Women's education } \\
\hline GCSE level or lower & $45.8 \%$ & $60.0 \%$ & $46.9 \%$ & $29.9 \%$ \\
\hline Some higher qualifications & $30.8 \%$ & $27.7 \%$ & $31.8 \%$ & $32.7 \%$ \\
\hline First degrees or above & $23.5 \%$ & $12.3 \%$ & $21.3 \%$ & $37.4 \%$ \\
\hline \multicolumn{5}{|l|}{ Men's education } \\
\hline GCSE level or lower & $43.2 \%$ & $51.6 \%$ & $44.1 \%$ & $33.7 \%$ \\
\hline Some higher qualifications & $34.3 \%$ & $33.3 \%$ & $34.8 \%$ & $34.8 \%$ \\
\hline First degrees or above & $22.5 \%$ & $15.1 \%$ & $21.1 \%$ & $31.5 \%$ \\
\hline \multicolumn{5}{|l|}{ Women's self-rated health } \\
\hline Excellent & $23.8 \%$ & $25.0 \%$ & $25.8 \%$ & $20.3 \%$ \\
\hline Good & $46.1 \%$ & $47.8 \%$ & $50.0 \%$ & $40.0 \%$ \\
\hline Fair & $21.2 \%$ & $19.6 \%$ & $17.3 \%$ & $27.3 \%$ \\
\hline Poor & $8.9 \%$ & $7.7 \%$ & $6.9 \%$ & $12.3 \%$ \\
\hline \multicolumn{5}{|l|}{ Men's self-rated health } \\
\hline Excellent & $26.1 \%$ & $29.4 \%$ & $28.7 \%$ & $19.9 \%$ \\
\hline Good & $45.5 \%$ & $46.6 \%$ & $48.9 \%$ & $40.4 \%$ \\
\hline Fair & $20.9 \%$ & $17.5 \%$ & $17.6 \%$ & $28.3 \%$ \\
\hline Poor & $7.5 \%$ & $6.5 \%$ & $4.9 \%$ & $11.4 \%$ \\
\hline
\end{tabular}


Table 1: (Continued)

\begin{tabular}{|c|c|c|c|c|}
\hline & All & 1991 to 2000 & 2001 to 2008 & 2009 to 2017 \\
\hline \multicolumn{5}{|l|}{ Women's race } \\
\hline White & $93.7 \%$ & $96.0 \%$ & $95.7 \%$ & $89.2 \%$ \\
\hline Black & $0.8 \%$ & $0.6 \%$ & $0.5 \%$ & $1.4 \%$ \\
\hline Asian & $4.6 \%$ & $3.0 \%$ & $3.5 \%$ & $7.3 \%$ \\
\hline Others & $0.9 \%$ & $0.4 \%$ & $0.3 \%$ & $2.1 \%$ \\
\hline Women being religious & $52.1 \%$ & $58.7 \%$ & $52.1 \%$ & $45.4 \%$ \\
\hline \multicolumn{5}{|l|}{ Location } \\
\hline England & $87.4 \%$ & $87.1 \%$ & $87.2 \%$ & $88.1 \%$ \\
\hline Wales & $4.5 \%$ & $4.7 \%$ & $4.5 \%$ & $4.4 \%$ \\
\hline Scotland & $8.1 \%$ & $8.3 \%$ & $8.3 \%$ & $7.5 \%$ \\
\hline \multicolumn{5}{|l|}{ Division of labor type } \\
\hline Male-breadwinner & $27.8 \%$ & $31.4 \%$ & $27.1 \%$ & $24.8 \%$ \\
\hline Modified male-breadwinner & $23.1 \%$ & $21.6 \%$ & $25.8 \%$ & $21.6 \%$ \\
\hline Dual-earner & $39.3 \%$ & $37.8 \%$ & $39.1 \%$ & $41.1 \%$ \\
\hline Female-breadwinner & $3.2 \%$ & $2.8 \%$ & $2.8 \%$ & $4.3 \%$ \\
\hline Precarious & $6.6 \%$ & $6.5 \%$ & $5.3 \%$ & $8.3 \%$ \\
\hline Couples & 12,888 & 3,692 & 3,052 & 9,008 \\
\hline Couple-year observations & 60,548 & 15,681 & 13,205 & 31,662 \\
\hline
\end{tabular}

Note: FT represents 'full-time.' PT represents 'part-time.' Median value reported. The same couple can be observed in different periods. Sums of percentages for discrete variables may differ slightly from $100 \%$ because of rounding.

Approximately $70 \%$ of the couples have children younger than age 15 in their households. The mean ages for women and men are about one year older in the latest sample than in the 1991 to 2000 sample, reflecting delayed union formation. More couples are cohabiting rather than being married, but the stability of the partnerships seems to remain unchanged, with similar partnership durations across the three periods. Couples' educational levels have improved substantially over the years.

\subsection{Five division of labor types}

The LCA identifies five couple-level division of labor types (see Table 2). Based on the response pattern of the three indicators, we name and order the division of labor as the male-breadwinner type (most traditional, 27.8\%), the modified male-breadwinner type $(23.1 \%)$, the dual-earner type $(39.3 \%)$, the female-breadwinner type (least traditional, $3.2 \%)$, and the precarious type $(6.6 \%)$. 
Table 2: Item response probabilities conditional on latent class membership

\begin{tabular}{|c|c|c|c|c|c|}
\hline \multirow{2}{*}{ Employment status of the couple } & \multirow[t]{2}{*}{$\begin{array}{l}\text { Male- } \\
\text { breadwinner }\end{array}$} & \multicolumn{2}{|c|}{$\begin{array}{l}\text { Modified male- Dual-earner } \\
\text { breadwinner }\end{array}$} & \multirow[t]{2}{*}{$\begin{array}{l}\text { Female- } \\
\text { breadwinner }\end{array}$} & \multirow[t]{2}{*}{ Precarious } \\
\hline & & & & & \\
\hline Women FT Working x Men FT Working & $0.2 \%$ & $28.3 \%$ & $93.1 \%$ & $17.2 \%$ & $15.2 \%$ \\
\hline Women FT Working x Men PT/Nonworking & $0.1 \%$ & $0.0 \%$ & $1.3 \%$ & $64.5 \%$ & $2.3 \%$ \\
\hline Women PT Working x Men FT Working & $27.5 \%$ & $66.7 \%$ & $4.9 \%$ & $0.1 \%$ & $0.9 \%$ \\
\hline Women PT Working x Men PT/Nonworking & $0.0 \%$ & $0.7 \%$ & $0.0 \%$ & $12.3 \%$ & $20.3 \%$ \\
\hline Women Nonworking x Men FT Working & $65.6 \%$ & $4.3 \%$ & $0.2 \%$ & $0.0 \%$ & $0.3 \%$ \\
\hline \multirow[t]{2}{*}{ Women Nonworking x Men PT/Nonworking } & $6.5 \%$ & $0.0 \%$ & $0.4 \%$ & $5.9 \%$ & $60.9 \%$ \\
\hline & $100 \%$ & $100 \%$ & $100 \%$ & $100 \%$ & $100 \%$ \\
\hline \multicolumn{6}{|l|}{ Women's share of income } \\
\hline Women share $<20 \%$ income & $73.1 \%$ & $13.3 \%$ & $1.6 \%$ & $0.5 \%$ & $10.9 \%$ \\
\hline Women share $20 \%-40 \%$ income & $17.5 \%$ & $66.4 \%$ & $24.3 \%$ & $4.0 \%$ & $19.2 \%$ \\
\hline Women share $40 \%-60 \%$ income & $7.4 \%$ & $15.8 \%$ & $61.7 \%$ & $10.1 \%$ & $30.7 \%$ \\
\hline \multirow[t]{2}{*}{ Women share $>60 \%$ income } & $2.0 \%$ & $4.5 \%$ & $12.4 \%$ & $85.4 \%$ & $39.2 \%$ \\
\hline & $100 \%$ & $100 \%$ & $100 \%$ & $100 \%$ & $100 \%$ \\
\hline \multicolumn{6}{|l|}{ Wife's share of housework } \\
\hline Women share $<50 \%$ housework & $3.7 \%$ & $7.3 \%$ & $21.3 \%$ & $46.4 \%$ & $16.1 \%$ \\
\hline Women share $50 \%-75 \%$ housework & $19.4 \%$ & $33.5 \%$ & $47.1 \%$ & $37.1 \%$ & $38.2 \%$ \\
\hline Women share $75 \%-90 \%$ housework & $34.6 \%$ & $34.0 \%$ & $22.7 \%$ & $11.4 \%$ & $21.2 \%$ \\
\hline \multirow[t]{2}{*}{ Women share $>90 \%$ housework } & $42.4 \%$ & $25.1 \%$ & $8.9 \%$ & $5.1 \%$ & $24.5 \%$ \\
\hline & $100 \%$ & $100 \%$ & $100 \%$ & $100 \%$ & $100 \%$ \\
\hline Level of gender traditionalism & \multicolumn{2}{|c|}{ Higher } & \multicolumn{2}{|c|}{ Lower } & Mixed \\
\hline Total (weighted) & $27.8 \%$ & $23.1 \%$ & $39.3 \%$ & $3.2 \%$ & $6.6 \%$ \\
\hline
\end{tabular}

Conditional on membership in the 'male-breadwinner' type, the probability that the wife does not work and the husband works full-time is 0.656 , and the probability that she works part-time and he works full-time is 0.275 . Not surprisingly, more than $90 \%$ of these couples have wives who contribute less than $40 \%$ of the total income. In these couples, the probability that she does more than $75 \%$ of the housework is 0.770 . These couples demonstrate a typical gender specialization model, with the husband as the key breadwinner and wife as the primary homemaker.

The 'modified male-breadwinner' type is predominately couples with part-time working wives and full-time working husbands, but they still have a 0.283 probability of being dual full-time workers. Wives share a majority of the housework and contribute a relatively small proportion of household income for this type.

The 'dual-earner' type, which is the largest group, features dual earners who work full-time. Even among them, only $61.7 \%$ of these couples with the wife and husband making similar contributions to the household income. And $26 \%$ of couples with the same employment status still have the husband outearning the wife, and $78.7 \%$ of these couples have the wives doing a larger share of housework. Nevertheless, this division of labor type best fits the egalitarian family model. 
Among the 'female-breadwinner' couples, they are most likely to be composed of a full-time working wife and a part-time working or nonworking husband, and $85.4 \%$ of the wives are primary earners. However, only about $46 \%$ of the wives do less than $50 \%$ of the housework. This group of couples accounts for only $3.2 \%$ of all couples. The last group is classified as the 'precarious' type because they are mostly composed of underemployed couples. There is no clear pattern of the gender division of labor. In the later sections, we focus on the first three groups in Table 2, which account for more than $90 \%$ of the observations.

The increase in women's share of total income and the decline in women's share of housework over the years, as reflected in Table 1, imply that the distribution of the different division of labor types should have changed. Figure 2 displays the trend of the distribution of the five types of division of labor from 1991 to 2017. Over time, the proportion of the dual-earner type increases, and the proportion of the malebreadwinner type decreases. The proportion of the more traditional type increases first and then declines. The surge of the precarious division of labor after 2008/2009 may reflect the impact of the economic recession.

\section{Figure 2: Weighted distribution of the five types of the division of labor for the} selected couples, 1991 to 2017

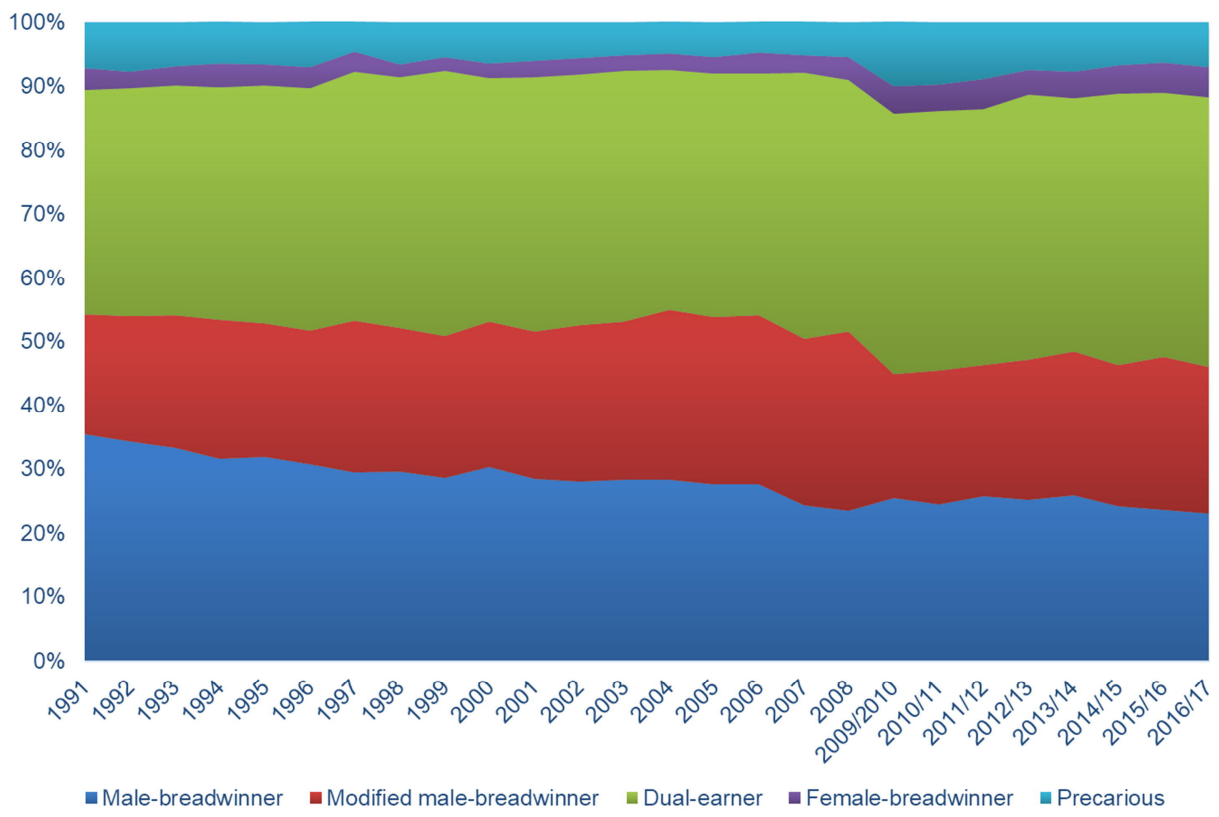


Next, for a descriptive purpose, we use the multinomial logistic regression models to show correlations between the division of labor and parenthood status as well as whether the likelihood of falling into a specific division of labor type has changed over time. The reference category is the dual-earner type, allowing us to compare predictors in other classes to this one. We use a full sample, a sample of childless couples, and a sample of parents to identify the key group with a changed distribution of division of labor. Tables 3 and 4 present the selected coefficients. ${ }^{18}$

\section{Table 3: Cross-sectional multinomial logistic regressions predicting the log odds of belonging to a certain division of labor type rather than the dual-earner one}

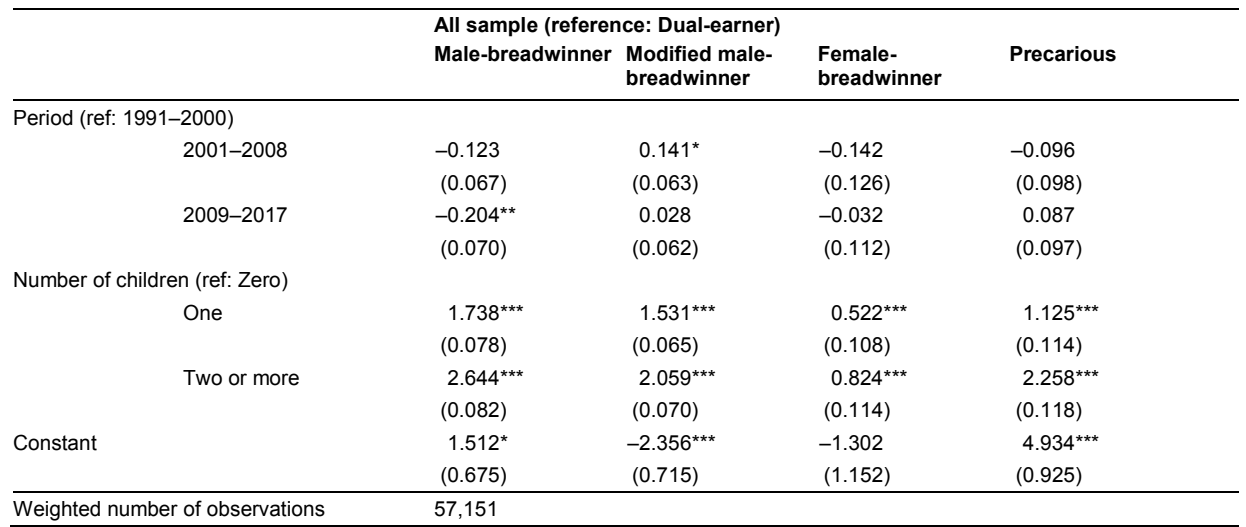

Note: Models also include whether cohabiting, partnership duration, couples' age and age square, educational attainments, selfrated health, women being religious, women's race, and location. Models are weighted with population-equilibrated cross-sectional weight. Please refer to Appendix Table A-1 for a list of all the coefficients. ${ }^{\star} p<.05^{\star \star} p<.01{ }^{\star \star *} p<.001$.

\footnotetext{
${ }^{18}$ Appendix Table A-1 reports a full list of coefficients in Table 3.
} 
Table 4: Cross-sectional multinomial logistic regressions predicting the log odds of belonging to a certain division of labor type rather than the dual-earner one by childless couples and parents

\begin{tabular}{|c|c|c|c|c|c|c|c|c|}
\hline & \multicolumn{4}{|c|}{ Childless couples (reference: Dual-earner) } & \multicolumn{3}{|c|}{ Parents (reference: Dual-earner) } & \multirow[b]{2}{*}{ Precarious } \\
\hline & $\begin{array}{l}\text { Male-bread- } \\
\text { winner }\end{array}$ & $\begin{array}{l}\text { - Modified } \\
\text { male-bread } \\
\text { winner }\end{array}$ & $\begin{array}{l}\text { Female- } \\
\text { - bread- } \\
\text { winner }\end{array}$ & Precarious & $\begin{array}{l}\text { Male-bread- } \\
\text { winner }\end{array}$ & $\begin{array}{l}\text { Modified } \\
\text { male-bread- } \\
\text { winner }\end{array}$ & $\begin{array}{l}\text { Female- } \\
\text { - bread- } \\
\text { winner }\end{array}$ & \\
\hline \multicolumn{9}{|l|}{ Period (ref: 1991-2000) } \\
\hline $2001-2008$ & $\begin{array}{l}-0.019 \\
(0.146)\end{array}$ & $\begin{array}{c}0.026 \\
(0.115)\end{array}$ & $\begin{array}{c}-0.248 \\
(0.165)\end{array}$ & $\begin{array}{c}0.318 \\
(0.235)\end{array}$ & $\begin{array}{r}-0.182^{*} \\
(0.081)\end{array}$ & $\begin{array}{c}0.142 \\
(0.078)\end{array}$ & $\begin{array}{l}-0.143 \\
(0.188)\end{array}$ & $\begin{array}{r}-0.258^{*} \\
(0.115)\end{array}$ \\
\hline 2009-2017 & $\begin{array}{c}0.029 \\
(0.135)\end{array}$ & $\begin{array}{c}0.148 \\
(0.105)\end{array}$ & $\begin{array}{c}-0.103 \\
(0.171)\end{array}$ & $\begin{array}{c}0.542^{*} \\
(0.218)\end{array}$ & $\begin{array}{l}-0.331^{\text {**}} \\
(0.084)\end{array}$ & $\begin{array}{c}-0.049 \\
(0.076)\end{array}$ & $\begin{array}{c}-0.082 \\
(0.147)\end{array}$ & $\begin{array}{c}-0.153 \\
(0.112)\end{array}$ \\
\hline \multicolumn{9}{|c|}{ Number of children (ref: One) } \\
\hline Two or more & & & & & $\begin{array}{l}0.964^{\star \star *} \\
(0.064)\end{array}$ & $\begin{array}{l}0.564^{\star \star \star} \\
(0.056)\end{array}$ & $\begin{array}{l}0.355^{\star \star \star} \\
(0.105)\end{array}$ & $\begin{array}{l}1.203^{\star \star \star} \\
(0.095)\end{array}$ \\
\hline Constant & $\begin{array}{c}-0.062 \\
(1.345)\end{array}$ & $\begin{array}{c}0.786 \\
(1.159)\end{array}$ & $\begin{array}{c}-1.722 \\
(1.442)\end{array}$ & $\begin{array}{c}3.260 \\
(1.871)\end{array}$ & $\begin{array}{l}5.362^{\star \star \star} \\
(0.928)\end{array}$ & $\begin{array}{c}0.021 \\
(0.961)\end{array}$ & $\begin{array}{c}2.135 \\
(1.972)\end{array}$ & $\begin{array}{l}8.429^{\star \star \star} \\
(1.181)\end{array}$ \\
\hline $\begin{array}{l}\text { Weighted number of } \\
\text { observations }\end{array}$ & 16,553 & & & & 40,598 & & & \\
\hline
\end{tabular}

Note: Models also include whether cohabiting, partnership duration, couples' age and age square, educational attainments, selfrated health, women being religious, women's race, and location. Models are weighted with population-equilibrated cross-sectional weight. ${ }^{*} p<.05^{* *} p<.01{ }^{* * *} p<.001$.

Results from the full sample (Table 3) show that over time, couples are $18.4 \%$ $\left(1-\mathrm{e}^{-0.204}\right)$ less likely to be classified into the male-breadwinner type as opposed to the dual-earner one. When the full sample is divided into childless couples and parents, it is shown that this trend is driven by changes only among parents (Table 4). Compared to parents observed in the reference period of 1991 to 2000 , those observed in the period of 2009 and 2017 are $28.2 \%\left(1-\mathrm{e}^{-0.331}\right)$ less likely to be classified into the male-breadwinner type rather than into the dual-earner one. This finding implies a change in the relationship between the division of labor and parenthood. Besides, childless couples are more likely to be classified into the precarious type. This may be associated with the worsening macroeconomic conditions after 2008 because the economic recession disproportionately affected lower-class men and led to an increase in no-earner households (Sani 2017).

Parenthood is a significant factor correlated with the division of labor. In the full sample (Table 3), couples with more children are more likely to be classified into any division of labor type other than the dual-earner one. This is even true for the femalebreadwinner type, although the size of the coefficients is the smallest. This correlation between underemployment and parenthood, even for men, is also found in previous studies, highlighting men's cost of childrearing (Baizán 2007; Dill and Frech 2018; Inanc 2015; Schmitt 2012). The social welfare system, which could compensate the financial pressure brought by underemployment and childrearing, may be one reason. Meanwhile, given the limited and expensive childcare services, childrearing in 
countries like the United Kingdom becomes extremely time-consuming. Therefore, underemployed couples in the United Kingdom may have limited financial pressure but are rich in time to rear more children.

\subsection{The effect of the division of labor on fertility}

The above results show that over the years, parents are less likely to be classified into the male-breadwinner type. This change indicates that the relationship between fertility and the division of labor may have changed. In what follows, we first examine whether the division of labor has any effect on childbearing. Specifically, we would like to examine that, in different periods, whether the (positive) effect of adopting a malebreadwinner model (vs. a dual-earner one) on the likelihood of having a child would be the same. A couple-level fixed-effect logistic model (Equation 1) is used to predict the odds of having a new child. Those who are going to have a new child within the next 12 months $(6.2 \%$ of the sample) are dropped to minimize the potential anticipation effect or the impact of physiological or medical reasons on women's working time. Because this is a logistic fixed-effect regression analysis, only those couples $(2,246)$ who do experience a change in the number of children are analyzed. ${ }^{19}$ The results of the key estimated coefficients are reported in Table 5.

\footnotetext{
${ }^{19}$ Please refer to Note 9 for sample selection concerns. Now we have couples who had a change in the number of children during the observational period. In certain couple-wave pairs, there was a change, but in other couple-wave pairs, this change did not happen. Fixed-effect regressions ask in which two pairs this event is more likely to happen. For $53 \%$ of the time a couple in this sample displays a dual-earner model, $55 \%$ of the time a male-breadwinner type, $42 \%$ of the time a modified male-breadwinner type, $31 \%$ a femalebreadwinner type, and $44 \%$ the couple displays a precarious couple type.
} 
Table 5: Fixed-effect logistic regressions predicting the log odds of having a child associated with the division of labor type

\begin{tabular}{lcc}
\hline & All births & Interaction \\
\hline Division of labor type (ref: dual-earner) & Basic & $0.933^{\star \star *}$ \\
Male-breadwinner & $0.376^{* \star}$ & $(0.182)$ \\
Modified male-breadwinner & $(0.115)$ & $0.540^{* \star}$ \\
Female-breadwinner & $0.248^{*}$ & $(0.173)$ \\
& $(0.103)$ & 0.042 \\
Precarious & 0.052 & $(0.216)$ \\
& $(0.216)$ & 0.279 \\
Period (ref: 1991-2000) & 0.292 & $(0.168)$ \\
2001-2008 & $(0.166)$ & -0.170 \\
& & $(0.183)$ \\
2009-2017 & $-0.401^{* *}$ & 0.263 \\
& $(0.143)$ & $(0.273)$ \\
Interactions & -0.169 & \\
Male-breadwinner * 2001-2008 & $(0.253)$ & $-0.527^{*}$ \\
Modified male-breadwinner * 2001-2008 & & $(0.217)$ \\
Male-breadwinner * 2009-2017 & & -0.307 \\
& & $(0.226)$ \\
Modified male-breadwinner * 2009-2017 & & $-0.989^{\star \star *}$ \\
& & $(0.227)$ \\
Couples & & $-0.473^{*}$ \\
Couple-year observations & & $(0.224)$ \\
\hline
\end{tabular}

Note: Records where a new child observed within the next 12 months are dropped. These models include number of children, wife's age and its squared term, husband's age and its squared term, cohabitation, duration of partnership, and number of years until the next observation. Standard errors are in parentheses. ${ }^{*} p<.05^{* *} p<.01{ }^{* \star *} p<.001$.

First, the basic model compares couples with different division of labor arrangements. The results show that the odds of having a new child in the next observation is $46 \%\left(e^{0.376}-1\right)$ higher if a couple adopts a male-breadwinner model rather than the dual-earner one. Then, we include interaction terms between the malebreadwinner and the modified male-breadwinner types and the period indicator. ${ }^{20}$ The statistically significant negative estimates of the interaction terms indicate the variations in the relationship between the division of labor and fertility. The positive effect of the male-breadwinner model on the birth of a child has declined significantly in later

${ }^{20}$ We also interact all the division of labor categories with the period indicator. First, the estimates of the male-breadwinner and the modified male-breadwinner types and their interactions with the period indicators remain unchanged. The shift into the precarious type is less likely to have a birth in later periods. Because of the small number of the observations of the female-breadwinner and the precarious types, which may render the results unstable, hence we do not report the details here. 
periods. For example, in the period of 1991 to 2000, the odds of having a new child almost triples $\left(e^{0.933}\right)$ if a couple adopts a male-breadwinner model rather than the dual-earner one. However, in the period of 2001 to 2008, the odds of having a new child increases only by $1.50\left(e^{0.933-0.527}\right)$ times with the same change in the division of labor. Most interestingly, from 2009 to 2017, the shift into the male-breadwinner arrangement has little effect $\left(e^{0.933-0.989}-1\right)$ on having a new child. The same trend also applies to the originally positive effect of the modified male-breadwinner type. We then calculate the exponentiation of the estimated coefficients and plot the odds ratio with a $95 \%$ confidence interval in each period in Figure 3. The reductions of the positive effects of the male-breadwinner and the modified male-breadwinner types over time are obvious. In summary, the positive effect on fertility associated with the traditional gendered division of labor declines over time.

\section{Figure 3: The effects (represented by odds ratio) of the division of labor type} on having a new child

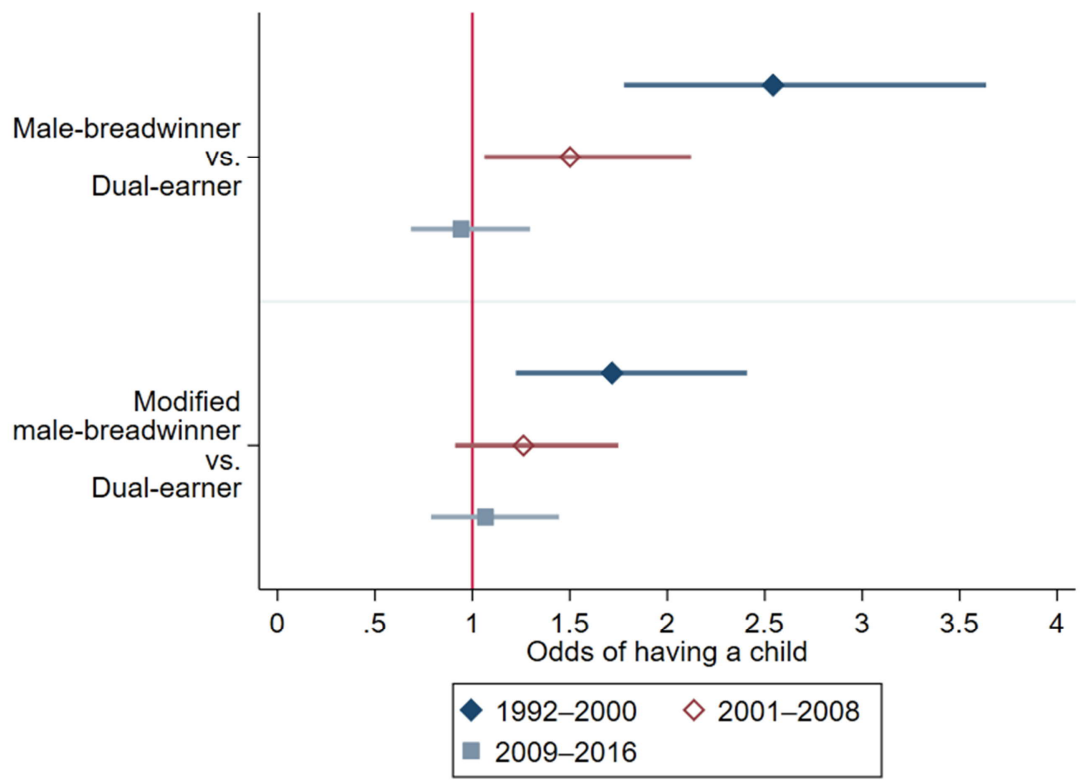




\subsection{The effect of parenthood on the division of labor}

This finding of a weakened positive effect of the specialization family model on having a child implies that the cost of parenthood may become less gender specific. That is, the traditionalizing effect of childrearing is expected to become weaker over the years.

We use the fixed-effect model introduced in Equation 2 to examine the traditionalizing effect of childbearing. Because the fixed-effect logistic regressions only analyze couples who have experienced a change in the division of labor, focusing on the specific transition between every two of the five types of division of labor would substantially reduce the sample size. To be consistent with the theory and to boost the occurrence of changes in the division of labor, we aggregate and rank the dual-earner and the female-breadwinner types into the less traditional group (the reference group) and the male-breadwinner and the modified male-breadwinner types into the more traditional group. ${ }^{21} \mathrm{We}$ then evaluate whether the shifts between the two groups and the number of children are associated. We have also excluded couples with children under the age of 1 and those women on maternity leave to minimize the impact of temporal disruptions to a couple's work-family arrangement. A total of 3,597 couples experienced a transition between these two groups. ${ }^{22}$ Table 6 presents the estimates from the fixed-effect logistic models.

\section{Table 6: Fixed-effect logistic regressions predicting the log odds of having more gendered division of labor associated with the number of children}

\begin{tabular}{ccc}
\hline & Basic & Interaction \\
\hline Number of children (ref: zero) & $2.562^{\star \star \star}$ & \\
One & $(0.102)$ & $2.998^{\star \star \star}$ \\
& $3.511^{\star \star \star}$ & $(0.165)$ \\
Two or more & $(0.129)$ & $4.413^{\star \star \star}$ \\
& & $(0.197)$ \\
Period (ref: $1991-2000)$ & $0.234^{\star \star}$ & \\
2001-2008 & $(0.085)$ & $0.778^{\star \star \star}$ \\
& 0.068 & $(0.148)$ \\
$2009-2017$ & $(0.154)$ & $1.019^{\star \star \star}$ \\
& & $(0.218)$ \\
\hline
\end{tabular}

${ }^{21}$ We have conducted the same analysis with more refined classifications, such as (1) the male-breadwinner type vs. the dual-earner type, (2) the modified male-breadwinner type vs. the dual-earner type, and (3) the male-breadwinner type vs. the modified male-breadwinner type. Precarious couples are not included in these analyses. The conclusion from each regression remains the same: the traditionalizing effect of parenthood gets weaker over the years. These tables are available upon requests to the authors.

${ }^{22}$ Please refer to Note 9 for sample selection concerns. 
Table 6: (Continued)

\begin{tabular}{|c|c|c|}
\hline & Basic & Interaction \\
\hline \multicolumn{3}{|l|}{ Number of children * Period } \\
\hline \multirow[t]{2}{*}{ One * 2001-2008 } & & $-0.503^{\star \star}$ \\
\hline & & $(0.174)$ \\
\hline \multirow[t]{2}{*}{ Two or more * 2001-2008 } & & $-1.053^{\star \star *}$ \\
\hline & & $(0.180)$ \\
\hline \multirow[t]{2}{*}{ One * 2009-2017 } & & $-0.882^{\star \star \star}$ \\
\hline & & $(0.192)$ \\
\hline \multirow[t]{2}{*}{ Two or more * 2009-2017 } & & $-1.537^{\star \star *}$ \\
\hline & & $(0.223)$ \\
\hline \multirow[t]{2}{*}{ Cohabitation } & $-0.266^{* *}$ & $-0.241^{\star *}$ \\
\hline & $(0.091)$ & $(0.089)$ \\
\hline \multirow[t]{2}{*}{ Partnership duration } & 0.005 & -0.017 \\
\hline & $(0.049)$ & $(0.050)$ \\
\hline \multirow[t]{2}{*}{ Women's age } & $-0.263^{*}$ & $-0.266^{*}$ \\
\hline & $(0.106)$ & $(0.105)$ \\
\hline \multirow[t]{2}{*}{ Women's age square } & $0.002+$ & $0.002^{*}$ \\
\hline & $(0.001)$ & $(0.001)$ \\
\hline \multirow[t]{2}{*}{ Men's age } & $0.303^{* *}$ & $0.296^{\star *}$ \\
\hline & $(0.100)$ & $(0.099)$ \\
\hline \multirow[t]{2}{*}{ Men's age square } & $-0.003^{\star \star \star}$ & $-0.003^{\star *}$ \\
\hline & $(0.001)$ & $(0.001)$ \\
\hline Couples & 3,597 & \\
\hline Couple-year observations & 26,439 & \\
\hline
\end{tabular}

Note: Standard errors are in parentheses. ${ }^{*} p<.05^{* \star} p<.01{ }^{\star \star *} p<.001$.

As expected, an increase in the number of children has a very strong traditionalizing effect on the division of labor. For instance, having one child is associated with multiplying the odds of being in the more traditional group by a factor of $12.96\left(e^{2.562}\right)$. Having two or more children is associated with multiplying the odds by 33.5 times $\left(e^{3.511}\right)$.

The time-varying effect of parenthood is reflected through interactions between the number of children and the period indicator. Estimates of this interaction term report whether the effect of the same change in the number of children in the latter two periods differs from that in the reference period of 1991 to 2000 . The negative estimates of the interaction terms show that the traditionalizing effect of the number of children becomes weaker. For example, an increase in the number of children from zero to one is associated with multiplying the odds of falling into the more traditional group by 20 times $\left(e^{2.998}\right)$ in the period of 1991 to 2000. However, from 2001 to 2008, when the same change in the number of children occurs, the odds of falling into the more traditional group is only associated with multiplying a factor of $12.12\left(e^{2.998-0.503}\right)$. Similarly, from 2009 to 2016, having one child is associated with multiplying the odds by a factor of only $8.30\left(e^{2.998-0.882}\right)$. The same trend is observed or even stronger for 
couples that are having two or more children. Based on this model, we plot the estimated odds ratio with a $95 \%$ confidence interval of the number of children in Figure 4. It is evident that this traditionalizing effect of childrearing gets weaker in later periods.

Figure 4: The effects (represented by odds ratio) of childrearing on the gendered division of labor

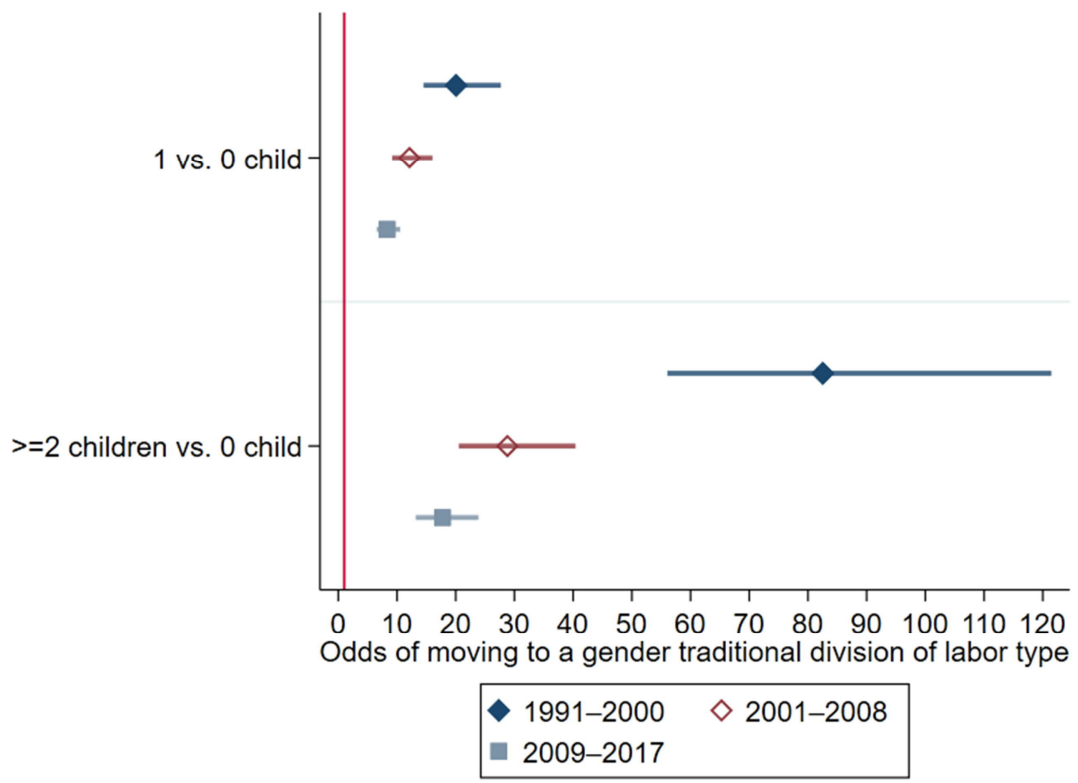

\section{Discussion and conclusion}

In this paper, we examine the relationship between the division of labor and fertility. More importantly, we investigate how this relationship has changed over the past three decades. Instead of relying on a single indicator to represent the level of gender equality among couples in previous studies, we use multiple indicators and LCA to construct a couple-level division of labor measure. We then use this measure to predict the couple's fertility behavior and reciprocally as a dependent variable to see how parenthood alters the division of labor. The weakening relationship between the traditional division of labor and fertility from 1991 to 2017 in Great Britain, as documented in this paper, 
reveals the most recent changes in micro-level family equilibrium among couples. Different from earlier work, which often misses out the time-varying dimension of the relationship between gender equality and fertility, our work contributes to the current literature by highlighting how the relationship between gender equality and family formation at a micro level evolves with the gender-revolution progress.

The use of a holistic couple-level approach to identify different levels of traditionalism in the division of labor has enabled a better measure of the gender equality level within couples because this division of labor classification considers (1) the division of labor in both the public and private spheres and (2) how the two spheres are matched. Economic resources play a determining role in shaping the division of labor because the five-class typology identified in this paper partly echoes earlier classifications solely based on employment match, such as the male-breadwinner, the 1.5 earner, and the dual full-time earner families (Connolly et al. 2016; Ellingsæter 2013). However, what is different is that our typology reveals a pattern that the same division of labor type includes various employment status matches, shares of income, and shares of housework. One example is that when a couple is classified as the relatively gender-egalitarian 'dual-earner' type, both the husband and the wife work full-time. However, couples who both work full-time may not necessarily belong to the egalitarian 'dual-earner' type because many of them share housework in a highly unequal way, and those couples should be grouped into the more traditional types, e.g., the 'modified male-breadwinner' type. Similarly, couples with women doing $50 \%$ to $75 \%$ of housework are conventionally considered to be egalitarian. However, those couples spread out across the five types once the couple's performance in the public sphere is considered. This complexity calls for a reconsideration of the meaning of gender equality within couples. Gender relations are reflected not only by how the earning power or housework are independently divided between spouses but also by how the division of labor in the two spheres is combined. Previous research, which uses a single indicator or multiple indicators additively, does not effectively capture the gender relation in marriage and is subject to the risk of misrepresenting the gender equality level within couples.

The question about whether the gendered division of labor and fertility are associated does not have a simple 'yes' or 'no' answer. Results confirm the timevarying relationship between the division of labor and fertility. The interactions with the period indicator enable the identification of the within-couple association between the division of labor and fertility in different periods. This methodological innovation differs from the common approach that could not differentiate between- and withincouple differences. We find out that couples adopting the male-breadwinner arrangement used to be more likely to have a new child than those with a dual-earner 
model. It is no longer the case now. This shift challenges the conventional assumption that the traditional family model is conducive to childrearing.

On the other hand, over the years, couples are much less likely to conform to the male-breadwinner female-housekeeper arrangement following the birth of a child. Changes in both directions reflect that the cost and expectation of parenthood are becoming less gender specific. The male-breadwinner specialization model, being developed in the context of substantial gender inequality, has started to lose its ground. Our findings support the gender revolution framework - the prevalence of egalitarian families will not hamper fertility with the continuation of the gender revolution. However, the argument of a fertility-promoting effect of gender equality has yet been supported.

This research is a pioneer in examining time-varying patterns in the dynamics between the division of labor and the birth of a child. The changing family equilibrium in Great Britain, reflected through the dampening positive relationship between the traditional gender division of labor and fertility, reveals the consequences of the undergoing gender revolution on family lives from the 1990s. We provide a few potential explanations here. For instance, women's economic position in the family is becoming increasingly important. As the economic uncertainties and difficulties grow, a dual-earner model increases the financial security of the family and is thus preferable than a traditional single-earner model. Over the years, fewer families would decide to follow the traditional division of labor or 'do gender' when they plan to or have become parents. Alternatively, the changing gender norms may also influence how people are selected into a stable partnership. Couples formed in later periods may hold more liberal gender attitudes than those formed in earlier periods. Accordingly, their fertility decision would not be strongly discouraged by a deviation from traditional gender roles, and their division of labor would be less affected by the transition into parenthood. Whether it is due to the period effect or the cohort effect that different people are selected into a partnership over the years is not the focus of this paper. Our paper, nevertheless, sheds light on how the relationships between alternative family models and fertility evolve from the 1990s within the gender revolution framework.

Our paper has a few limitations. First, the effect of the gendered division of labor on fertility may differ for the first birth or higher order births. Some prior work has noted that economic resources have greater constraints on the birth of a first child than higher order births (Dommermuth, Hohmann-Marriott, and Lappegård 2015; Kreyenfeld and Andersson 2014), but others do not find this difference (Miettinen, Lainiala, and Rotkirch 2015). In a supplementary analysis (Appendix Table A-2), we noted that compared to the dual-earner type, the male-breadwinner and precarious types seem to be less conducive for the first birth but more conducive for higher order births. Nevertheless, the pattern of a declining positive link between the male-breadwinner 
model on fertility over years is clear for both first and higher order births in the interaction models. Due to the small sample size that may render the estimates unreliable, we do not report the results in the main texts. We believe that future work with larger samples would provide valuable insights into the complexity of fertility decisions.

Second, this paper focuses extensively on changes in the micro-level relationship between gender equality and fertility within the gender revolution framework, and precarious couples where both spouses do not work full-time fall out of the scope of this paper. The number of these families is small but has been increasing over time in the past decade due to rising economic uncertainties. Previous work has found out that although precarious couples were more likely to have children than dual-earner ones in the past, it is less likely to be the case in more recent years in the United Kingdom (Inanc 2015). Economic uncertainties and difficulties are becoming more detrimental to childrearing over the years. Future research should investigate how the macro-level economic condition might moderate the relationship between precarity and fertility.

Despite these limitations, this paper contributes to the literature by illustrating that the association between the traditional division of labor and fertility has been evolving over time. The positive association between the traditional division of labor and fertility should be applicable in countries where the gender equality level is relatively low with significant conflicts between women's employment and childrearing responsibilities. In countries where the gender equality level is relatively high, and the childcare services are inexpensive and widely accessible, the association between the gendered division of labor and fertility could be weak, as what has just emerged in the United Kingdom in the late 2010s. Although we agree that the specific relationship between the gender division of labor and fertility differs across countries, the trend of a weakening positive relationship between the traditional gender division of labor and fertility is expected in developed countries where the gender revolution has been continuing for decades.

\section{Acknowledgements}

The first author extends sincere thanks to the Swire Charitable Trust for their financial support. The second author gratefully acknowledges funding by the Economic and Social Research Council (ESRC) through the Research Centre on Micro-Social Change at the University of Essex, grant number ES/L009153/1, and by the European Research Council (ERC) under the European Union's Horizon 2020 research and innovation programme, awardee: Man-Yee Kan, grant number 771736. 


\section{References}

Allison, P.D. (2009). Fixed effects regression models. Thousand Oaks: SAGE. doi:10.4135/9781412993869.

Altintas, E. and Sullivan, O. (2016). Fifty years of change updated: Cross-national gender convergence in housework. Demographic Research 35(16): 455-470. doi:10.4054/DemRes.2016.35.16.

Argyrous, G., Craig, L., and Rahman, S. (2016). The effect of a first born child on work and childcare time allocation: Pre-post analysis of Australian couples. Social Indicators Research online first: 24 February 2016. doi:10.1007/s11205-0161278-5.

Arpino, B., Esping-Andersen, G., and Pessin, L. (2015). How do changes in gender role attitudes towards female employment influence fertility? A macro-level analysis. European Sociological Review 31(3): 370-382. doi:10.1093/esr/jcv002.

Baizán, P. (2007). The impact of labour market status on second and higher-order births. In: Esping-Andersen, G. (ed.). Family formation and family dilemmas in contemporary Europe. Madrid: Fundación BBVA: 93-125.

Bakk, Z., Tekle, F.B., and Vermunt, J.K. (2013). Estimating the association between latent class membership and external variables using bias-adjusted three-step approaches. Sociological Methodology 43(1): 272-311. doi:10.1177/ 0081175012470644 .

Becker, G.S. (1976). The economic approach to human behavior. Chicago: University of Chicago Press. doi:10.7208/chicago/9780226217062.001.0001.

Becker, G.S. (1981). A treatise on the family. Cambridge: Harvard University Press.

Becker, G.S. (1985). Human capital, effort, and the sexual division of labor. Journal of Labor Economics 3(1, Part 2): S33-S58. doi:10.1086/298075.

Blossfeld, H.-P., Mills, M., Klijzing, E., and Kurz, K. (2008). Globalization, uncertainty and youth in society. New York: Routledge.

Brines, J. (1994). Economic dependency, gender, and the division of labor at home. American Journal of Sociology 100(3): 652-688. doi:10.1086/230577.

Brinton, M.C. and Lee, D.-J. (2016). Gender-role ideology, labor market institutions, and post-industrial fertility. Population and Development Review 42(3): 405433. doi:10.1111/padr.161. 
Connolly, S., Aldrich, M., O'Brien, M., Speight, S., and Poole, E. (2016). Britain's slow movement to a gender egalitarian equilibrium: Parents and employment in the UK 2001-13. Work, Employment and Society 30(5): 838-857. doi:10.1177/ 0950017016638009 .

Cooke, L.P. (2009). Gender equity and fertility in Italy and Spain. Journal of Social Policy 38(1): 123-140. doi:10.1017/S0047279408002584.

De Hauw, Y., Grow, A., and Van Bavel, J. (2017). The reversed gender gap in education and assortative mating in Europe. European Journal of Population 33(4): 445-474. doi:10.1007/s10680-016-9407-z.

de Laat, J. and Sevilla-Sanz, A. (2011). The fertility and women's labor force participation puzzle in OECD countries: The role of men's home production. Feminist Economics 17(2): 87-119. doi:10.1080/13545701.2011.573484.

Dill, J. and Frech, A. (2018). Providing for a family in the working class: Gender and employment after the birth of a child. Social Forces: soy106. doi:10.1093/ sf/soy106.

Dommermuth, L., Hohmann-Marriott, B., and Lappegård, T. (2015). Gender equality in the family and childbearing. Journal of Family Issues 38(13): 1803-1824. doi:10.1177/0192513X15590686.

Ellingsæter, A.L. (2013). Scandinavian welfare states and gender (de)segregation: Recent trends and processes. Economic and Industrial Democracy 34(3): 501518. doi:10.1177/0143831X13491616.

Esping-Andersen, G. (2016). Families in the $21^{\text {st }}$ century. Stockholm: SNS Förlag.

Esping-Andersen, G. and Billari, F.C. (2015). Re-theorizing family demographics. Population and Development Review 41(1): 1-31. doi:10.1111/j.1728-4457. 2015.00024.x.

Esping-Andersen, G., Boertien, D., Bonke, J., and Gracia, P. (2013). Couple specialization in multiple equilibria. European Sociological Review 29(6): 1280-1294. doi:10.1093/esr/jct004.

Evertsson, M. and Nermo, M. (2007). Changing resources and the division of housework: A longitudinal study of Swedish couples. European Sociological Review 23(4): 455-470. doi:10.1093/esr/jcm018.

Fahlén, S. (2016). Equality at home: A question of career? Housework, norms, and policies in a European comparative perspective. Demographic Research 35(48): 1411-1440. doi:10.4054/DemRes.2016.35.48. 
Gangl, M. and Ziefle, A. (2009). Motherhood, labor force behavior, and women's careers: An empirical assessment of the wage penalty for motherhood in Britain, Germany, and the United States. Demography 46(2): 341-369. doi:10.1353/ dem.0.0056.

Garey, A.I. (1999). Weaving work and motherhood. Philadelphia: Temple University Press.

Goldscheider, F., Bernhardt, E., and Lappegård, T. (2015). The gender revolution: A framework for understanding changing family and demographic behavior. Population and Development Review 41(2): 207-239. doi:10.1111/j.1728-4457. 2015.00045.x.

Hakim, C. (2000). Work-lifestyle choices in the $21^{\text {st }}$ century: Preference theory. Oxford: Oxford University Press.

Hakim, C. (2003). A new approach to explaining fertility patterns: Preference theory. Population and Development Review 29(3): 349-374. doi:10.1111/j.1728-4457. 2003.00349.x.

Hall, S.S. and MacDermid, S.M. (2009). A typology of dual earner marriages based on work and family arrangements. Journal of Family and Economic Issues 30(3): 215-225. doi:10.1007/s10834-009-9156-9.

Hays, S. (1996). The cultural contradictions of motherhood. New Haven: Yale University Press.

Inanc, H. (2015). Unemployment and the timing of parenthood: Implications of partnership status and partner's employment. Demographic Research 32(7): 219-250. doi:10.4054/DemRes.2015.32.7.

Jalovaara, M. and Miettinen, A. (2013). Does his paycheck also matter? The socioeconomic resources of co-residential partners and entry into parenthood in Finland. Demographic Research 28(31): 881-916. doi:10.4054/DemRes.2013. 28.31 .

Kan, M.-Y. and Gershuny, J. (2009). Gender and time use over the life-course. In: Brynin, M. and Ermisch, J. (eds.). Changing relationships. New York: Routledge: 146-160.

Kan, M.-Y. and Gershuny, J. (2010). Gender segregation and bargaining in domestic labour: Evidence from longitudinal time use data. In: Scott, J.L., Crompton, R., and Lyonette, C. (eds.). Gender inequalities in the $21^{\text {st }}$ century. Cheltenham: Edward Elgar: 153-173. doi:10.4337/9781849805568.00016. 
Kan, M.-Y. and Pudney, S. (2008). Measurement error in stylized and diary data on time use. Sociological Methodology 38(1): 101-132. doi:10.1111/j.1467-9531. 2008.00197.x.

Kan, M.-Y., Sullivan, O., and Gershuny, J. (2011). Gender convergence in domestic work: Discerning the effects of interactional and institutional barriers from large-scale data. Sociology 45(2): 234-251. doi:10.1177/0038038510394014.

Kaufman, G. (2000). Do gender role attitudes matter? Family formation and dissolution among traditional and egalitarian men and women. Journal of Family Issues 21(1): 128-144. doi:10.1177/019251300021001006.

Killewald, A. and García-Manglano, J. (2016). Tethered lives: A couple-based perspective on the consequences of parenthood for time use, occupation, and wages. Social Science Research 60: 266-282. doi:10.1016/j.ssresearch.2016. 03.007.

Kitterød, R.H. and Lappegård, T. (2012). A typology of work-family arrangements among dual-earner couples in Norway. Family Relations 61(4): 671-685. doi:10.1111/j.1741-3729.2012.00725.x.

Kolk, M. (2019). Weak support for a U-shaped pattern between societal gender equality and fertility when comparing societies across time. Demographic Research 40(2): 27-48. doi:10.4054/DemRes.2019.40.2.

Kolpashnikova, K. (2018). American househusbands: New time use evidence of gender display, 2003-2016. Social Indicators Research 140(3): 1259-1277. doi:10.1007/s11205-017-1813-z.

Kreyenfeld, M. and Andersson, G. (2014). Socioeconomic differences in the unemployment and fertility nexus: Evidence from Denmark and Germany. Advances in Life Course Research 21: 59-73. doi:10.1016/j.alcr.2014.01.007.

Kühhirt, M. (2012). Childbirth and the long-term division of labour within couples: How do substitution, bargaining power, and norms affect parents' time allocation in West Germany? European Sociological Review 28(5): 565-582. doi:10.1093/esr/jcr026.

Langner, L.A. (2015). Within-couple specialisation in paid work: A long-term pattern? A dual trajectory approach to linking lives. Advances in Life Course Research 24: 47-65. doi:10.1016/j.alcr.2015.02.002. 
Lesthaeghe, R. and Meekers, D. (1987). Value changes and the dimensions of familism in the European community. European Journal of Population 2(3-4): 225-268. doi:10.1007/BF01796593.

Luci-Greulich, A. and Thévenon, O. (2014). Does economic advancement 'cause' a reincrease in fertility? An empirical analysis for OECD countries (1960-2007). European Journal of Population 30(2): 187-221. doi:10.1007/s10680-013-93092.

Lundberg, S. and Pollak, R.A. (1993). Separate spheres bargaining and the marriage market. Journal of Political Economy 101(6): 988-1010. doi:10.1086/261912.

Lundström, K.E. and Andersson, G. (2012). Labor-market status, migrant status and first childbearing in Sweden. Demographic Research 27(25): 719-742. doi:10.4054/DemRes.2012.27.25.

Malthus, T.R. (1803). An essay on the principle of population, or: A view of its past and present effects on human happiness. London: Johnson.

Manser, M. and Brown, M. (1980). Marriage and household decision-making: A bargaining analysis. International Economic Review 21(1): 31-44. doi:10.2307/ 2526238 .

McCutcheon, A.L. (1987). Latent class analysis. Thousand Oaks: SAGE. doi:10.4135/ 9781412984713.

McDonald, P. (2000). Gender equity in theories of fertility transition. Population and Development Review 26(3): 427-439. doi:10.1111/j.1728-4457.2000.00427.x.

Mercer, R.T. (2004). Becoming a mother versus maternal role attainment. Journal of Nursing Scholarship 36(3): 226-232. doi:10.1111/j.1547-5069.2004.04042.x.

Miettinen, A., Lainiala, L., and Rotkirch, A. (2015). Women's housework decreases fertility: Evidence from a longitudinal study among Finnish couples. Acta Sociologica 58(2): 139-154. doi:10.1177/0001699315572028.

Mills, M., Begall, K., Mencarini, L., and Tanturri, M.L. (2008). Gender equity and fertility intentions in Italy and the Netherlands. Demographic Research 18(1): 1-26. doi:10.4054/DemRes.2008.18.1.

National Audit Office (2016). Entitlement to free early education and childcare. London: Department for Education (Report HC 853). https://www.nao.org.uk/ wp-content/uploads/2016/03/Entitlement-to-free-early-education-and-childcare. pdf. 
Neyer, G., Lappegård, T., and Vignoli, D. (2013). Gender equality and fertility: Which equality matters? European Journal of Population 29(3): 245-272. doi:10.1007/ s10680-013-9292-7.

OECD (2015). Education at a glance 2015: OECD indicators. Paris: OECD. doi:10.1787/eag-2015-en.

OECD (2017). Labour market statistics: Labour force statistics by sex and age: Indicators [electronic resource]. Paris: OECD. doi:10.1787/data-00310-en.

Office for National Statistics (2017). Gender pay gap tables by age groups [electronic resource]. Newport: Office for National Statistics. https://www.ons.gov.uk/ employmentandlabourmarket/peopleinwork/earningsandworkinghours/datasets/a nnualsurveyofhoursandearningsashegenderpaygaptables.

Oppenheimer, V.K. (1988). A theory of marriage timing. American Journal of Sociology 94(3): 563-591. doi:10.1086/229030.

Rindfuss, R.R., Choe, M.K., and Brauner-Otto, S.R. (2016). The emergence of two distinct fertility regimes in economically advanced countries. Population Research and Policy Review 35(3): 287-304. doi:10.1007/s11113-016-9387-z

Ruggles, S. (2015). Patriarchy, power, and pay: The transformation of American families, 1800-2015. Demography 52(6): 1797-1823. doi:10.1007/s13524-0150440-z.

Sani, G.M.D. (2017). The economic crisis and changes in work-family arrangements in six European countries. Journal of European Social Policy 28(2): 177-193.

Schmitt, C. (2012). Labour market integration, occupational uncertainty, and fertility choices in Germany and the UK. Demographic Research 26(12): 253-292. doi:10.4054/DemRes.2012.26.12.

Schober, P.S. (2013a). Gender equality and outsourcing of domestic work, childbearing, and relationship stability among British couples. Journal of Family Issues 34(1): 25-52. doi:10.1177/0192513X11433691.

Schober, P.S. (2013b). The parenthood effect on gender inequality: Explaining the change in paid and domestic work when British couples become parents. European Sociological Review 29(1): 74-85. doi:10.1093/esr/jcr041.

Scott, J. and Clery, E. (2013). Gender roles: An incomplete revolution? In: Park, A., Bryson, C., Clery, E., Curtice, J., and Phillips, M. (eds.). British social attitudes: The $30^{\text {th }}$ report. London: National Centre for Social Research: 115-138. http://www.bsa.natcen.ac.uk/media/38457/bsa30_gender_roles_final.pdf. 
Siegel, C. (2017). Female relative wages, household specialization and fertility. Review of Economic Dynamics 24: 152-174. doi:10.1016/j.red.2017.01.010.

Stryker, S. (1968). Identity salience and role performance: The relevance of symbolic interaction theory for family research. Journal of Marriage and Family 30(4): 558-564. doi:10.2307/349494.

Sullivan, O. (2013). What do we learn about gender by analyzing housework separately from child care? Some considerations from time-use evidence. Journal of Family Theory and Review 5(2): 72-84. doi:10.1111/jftr.12007.

Sullivan, O. and Gershuny, J. (2016). Change in spousal human capital and housework: A longitudinal analysis. European Sociological Review 32(6): 864-880. doi:10.1093/esr/jcw043.

Taylor, E.A. and Scott, J. (2018). Gender. In: Phillips, D., Curtice, J., Phillips, M., and Perry, J. (eds.). British social attitudes: The $35^{\text {th }}$ report. London: National Centre for Social Research. http://www.bsa.natcen.ac.uk/media/39248/bsa35_ gender.pdf.

Torr, B.M. and Short, S.E. (2004). Second Births and the second shift: A research note on gender equity and fertility. Population and Development Review 30(1):109130 .

Ukil, P. (2015). Effect of fertility on female labour force participation in the United Kingdom. Margin: The Journal of Applied Economic Research 9(2): 109-132. doi:10.1177/0973801014568145.

Van De Kaa, D.J. (1987). Europe's second demographic transition. Population Bulletin 42(1): 1-59.

Vignoli, D., Drefahl, S., and De Santis, G. (2012). Whose job instability affects the likelihood of becoming a parent in Italy? A tale of two partners. Demographic Research 26(2): 41-62. doi:10.4054/DemRes.2012.26.2.

West, C. and Zimmerman, D.H. (1987). Doing gender. Gender and Society 1(2): 125151. doi: $10.1177 / 0891243287001002002$.

Willis, R.J. (1973). A new approach to the economic theory of fertility behavior. Journal of Political Economy 81(2, Part 2): S14-S64. doi:10.1086/260152.

Wood, J. and Neels, K. (2016). First a job, then a child? Subgroup variation in women's employment-fertility link. Advances in Life Course Research 33: 38-52. doi:10.1016/j.alcr.2016.09.003. 
Zhou \& Kan: Changing dynamics between the gender division of labor and fertility in Great Britain

Zhou, M. (2017). Motherhood, employment, and the dynamics of women's gender attitudes. Gender and Society 31(6): 751-776. doi:10.1177/0891243217732320. 


\section{Appendix}

Table A-1: Cross-sectional multinomial logistic regressions predicting the log odds of belonging to a certain division of labor type

\begin{tabular}{|c|c|c|c|c|}
\hline & \multicolumn{2}{|c|}{ All sample (reference: Dual-earner) } & \multirow[b]{2}{*}{$\begin{array}{l}\text { Female- } \\
\text { breadwinner }\end{array}$} & \multirow[b]{2}{*}{ Precarious } \\
\hline & $\begin{array}{l}\text { Male- } \\
\text { breadwinner }\end{array}$ & $\begin{array}{l}\text { Modified male- } \\
\text { breadwinner }\end{array}$ & & \\
\hline \multicolumn{5}{|l|}{ Period (ref: 1991-2000) } \\
\hline \multirow[t]{2}{*}{$2001-2008$} & -0.123 & $0.141^{\star}$ & -0.142 & -0.096 \\
\hline & $(0.067)$ & $(0.063)$ & $(0.126)$ & $(0.098)$ \\
\hline \multirow[t]{2}{*}{ 2009-2017 } & $-0.204^{\star *}$ & 0.028 & -0.032 & 0.087 \\
\hline & $(0.070)$ & $(0.062)$ & $(0.112)$ & $(0.097)$ \\
\hline \multicolumn{5}{|c|}{ Number of children (ref: zero) } \\
\hline \multirow[t]{2}{*}{ One } & $1.738^{\star \star \star}$ & $1.531^{\star \star \star}$ & $0.522^{\star \star \star}$ & $1.125^{\star \star \star}$ \\
\hline & $(0.078)$ & $(0.065)$ & $(0.108)$ & $(0.114)$ \\
\hline \multirow[t]{2}{*}{ Two or more } & $2.644^{* * *}$ & $2.059^{\star \star \star}$ & $0.824^{* \star *}$ & $2.258^{\star \star \star}$ \\
\hline & $(0.082)$ & $(0.070)$ & $(0.114)$ & $(0.118)$ \\
\hline \multirow[t]{2}{*}{ Cohabitation } & $-0.200^{\star *}$ & $-0.187^{\star \star}$ & $0.487^{\star \star \star}$ & $0.490^{\star \star \star}$ \\
\hline & $(0.073)$ & $(0.065)$ & $(0.115)$ & $(0.097)$ \\
\hline \multirow[t]{2}{*}{ Partnership duration } & 0.007 & 0.010 & 0.001 & -0.005 \\
\hline & $(0.007)$ & $(0.006)$ & $(0.010)$ & $(0.010)$ \\
\hline \multirow[t]{2}{*}{ Women's age } & $-0.223^{\star * *}$ & -0.044 & 0.037 & $-0.382^{\star \star \star}$ \\
\hline & $(0.047)$ & $(0.045)$ & $(0.091)$ & $(0.067)$ \\
\hline \multirow[t]{2}{*}{ Women's age square } & $0.003^{* \star *}$ & 0.001 & -0.001 & $0.005^{\star \star \star}$ \\
\hline & $(0.001)$ & $(0.001)$ & $(0.001)$ & $(0.001)$ \\
\hline \multirow[t]{2}{*}{ Men's age } & 0.046 & $0.070^{*}$ & $-0.186^{* *}$ & -0.087 \\
\hline & $(0.038)$ & $(0.033)$ & $(0.062)$ & $(0.046)$ \\
\hline \multirow[t]{2}{*}{ Men's age square } & -0.000 & $-0.001^{*}$ & $0.003^{* \star *}$ & $0.001^{\text {** }}$ \\
\hline & $(0.000)$ & $(0.000)$ & $(0.001)$ & $(0.001)$ \\
\hline \multirow{2}{*}{\multicolumn{5}{|c|}{$\begin{array}{l}\text { Women's education } \\
\text { (ref: GCSE or lower) }\end{array}$}} \\
\hline & & & & \\
\hline \multirow[t]{2}{*}{ A-level/other higher } & $-0.654^{\star \star \star}$ & $-0.318^{\star \star *}$ & -0.062 & $-1.174^{\star \star \star}$ \\
\hline & $(0.081)$ & $(0.069)$ & $(0.133)$ & $(0.097)$ \\
\hline \multirow[t]{2}{*}{$1^{\text {st }}$ degree+ } & $-1.303^{\star \star *}$ & $-0.669^{\star \star \star}$ & 0.274 & $-1.324^{\star \star \star}$ \\
\hline & $(0.101)$ & $(0.084)$ & $(0.158)$ & $(0.137)$ \\
\hline \multirow{2}{*}{\multicolumn{5}{|c|}{$\begin{array}{l}\text { Men's education } \\
\text { (ref: GCSE or lower) }\end{array}$}} \\
\hline & & & & \\
\hline \multirow[t]{2}{*}{ A-level/other higher } & 0.030 & -0.003 & -0.192 & $-0.601^{\star \star \star}$ \\
\hline & $(0.078)$ & $(0.067)$ & $(0.132)$ & $(0.096)$ \\
\hline \multirow[t]{2}{*}{$1^{\text {st }}$ degree+ } & $0.551^{* * *}$ & 0.088 & -0.130 & $-0.435^{\star \star}$ \\
\hline & $(0.100)$ & $(0.085)$ & $(0.156)$ & $(0.142)$ \\
\hline \multicolumn{5}{|l|}{$\begin{array}{l}\text { Women's self-rated health } \\
\text { (ref: excellent) }\end{array}$} \\
\hline \multirow[t]{2}{*}{ Good } & 0.026 & -0.005 & -0.141 & 0.073 \\
\hline & $(0.061)$ & $(0.057)$ & $(0.109)$ & $(0.101)$ \\
\hline \multirow[t]{2}{*}{ Fair } & $0.258^{\star \star \star}$ & 0.021 & 0.005 & $0.612^{\star \star \star}$ \\
\hline & $(0.071)$ & $(0.066)$ & $(0.120)$ & $(0.114)$ \\
\hline \multirow[t]{2}{*}{ Poor } & $0.858^{\star \star \star}$ & 0.069 & -0.102 & $1.633^{\star \star \star}$ \\
\hline & $(0.097)$ & $(0.090)$ & $(0.153)$ & $(0.129)$ \\
\hline
\end{tabular}


Zhou \& Kan: Changing dynamics between the gender division of labor and fertility in Great Britain

Table A-1: (Continued)

\begin{tabular}{|c|c|c|c|c|}
\hline & \multicolumn{4}{|c|}{ All sample (reference: Dual-earner) } \\
\hline & $\begin{array}{l}\text { Male- } \\
\text { breadwinner }\end{array}$ & $\begin{array}{l}\text { Modified male- } \\
\text { breadwinner }\end{array}$ & $\begin{array}{l}\text { Female- } \\
\text { breadwinner }\end{array}$ & Precarious \\
\hline \multicolumn{5}{|l|}{$\begin{array}{l}\text { Men's self-rated health } \\
\text { (ref: excellent) }\end{array}$} \\
\hline Good & $\begin{array}{l}-0.115^{\star} \\
(0.057)\end{array}$ & $\begin{array}{l}-0.015 \\
(0.050)\end{array}$ & $\begin{array}{c}0.264^{*} \\
(0.118)\end{array}$ & $\begin{array}{l}-0.088 \\
(0.090)\end{array}$ \\
\hline Fair & $\begin{array}{c}-0.187^{\star \star} \\
(0.070)\end{array}$ & $\begin{array}{c}-0.065 \\
(0.062)\end{array}$ & $\begin{array}{l}0.705^{\star \star \star} \\
(0.131)\end{array}$ & $\begin{array}{l}0.381^{\star \star *} \\
(0.101)\end{array}$ \\
\hline Poor & $\begin{array}{c}0.055 \\
(0.095)\end{array}$ & $\begin{array}{r}-0.176^{*} \\
(0.090)\end{array}$ & $\begin{array}{l}1.758^{\star \star \star} \\
(0.153)\end{array}$ & $\begin{array}{l}1.567^{* * *} \\
(0.117)\end{array}$ \\
\hline \multicolumn{5}{|l|}{ Women' race (ref: white) } \\
\hline Black & $\begin{array}{l}-0.550^{*} \\
(0.261)\end{array}$ & $\begin{array}{l}-0.783^{* *} \\
(0.282)\end{array}$ & $\begin{array}{c}0.404 \\
(0.270)\end{array}$ & $\begin{array}{l}0.783^{* *} \\
(0.262)\end{array}$ \\
\hline Asian & $\begin{array}{r}0.390^{*} \\
(0.169)\end{array}$ & $\begin{array}{l}-0.234 \\
(0.154)\end{array}$ & $\begin{array}{c}0.403 \\
(0.273)\end{array}$ & $\begin{array}{l}0.710^{* * *} \\
(0.202)\end{array}$ \\
\hline Others & $\begin{array}{c}0.310 \\
(0.234)\end{array}$ & $\begin{array}{l}-0.289 \\
(0.195)\end{array}$ & $\begin{array}{l}-0.370 \\
(0.456)\end{array}$ & $\begin{array}{c}0.686^{*} \\
(0.327)\end{array}$ \\
\hline Women being religious & $\begin{array}{c}0.044 \\
(0.063)\end{array}$ & $\begin{array}{c}0.053 \\
(0.055)\end{array}$ & $\begin{array}{c}0.015 \\
(0.093)\end{array}$ & $\begin{array}{c}0.035 \\
(0.088)\end{array}$ \\
\hline \multicolumn{5}{|l|}{ Location (ref: England) } \\
\hline Wales & $\begin{array}{l}-0.368^{\star \star \star} \\
(0.107)\end{array}$ & $\begin{array}{r}-0.234^{*} \\
(0.093)\end{array}$ & $\begin{array}{c}0.217 \\
(0.157)\end{array}$ & $\begin{array}{c}0.140 \\
(0.151)\end{array}$ \\
\hline Scotland & $\begin{array}{l}-0.251^{* \star} \\
(0.092)\end{array}$ & $\begin{array}{c}0.059 \\
(0.077)\end{array}$ & $\begin{array}{c}0.038 \\
(0.137)\end{array}$ & $\begin{array}{c}0.142 \\
(0.129)\end{array}$ \\
\hline Constant & $\begin{array}{r}1.512^{\star} \\
(0.675)\end{array}$ & $\begin{array}{l}-2.356^{\star \star *} \\
(0.715)\end{array}$ & $\begin{array}{l}-1.302 \\
(1.152)\end{array}$ & $\begin{array}{l}4.934^{* * *} \\
(0.925)\end{array}$ \\
\hline Weighted number of observations & 57,151 & & & \\
\hline
\end{tabular}

Note: Models are weighted with population-equilibrated cross-sectional weight. Standard errors are in parentheses. ${ }^{*} p<.05{ }^{\star *} p<.01$ ${ }^{* * \star} p<.001$.

Table A-2: Fixed-effect logistic regressions predicting the log odds of having a child associated with the division of labor type, by parity

\begin{tabular}{|c|c|c|c|c|}
\hline & \multicolumn{2}{|c|}{ First birth } & \multicolumn{2}{|c|}{ Second/higher order births } \\
\hline & Basic & Interaction & Basic & Interaction \\
\hline \multicolumn{5}{|l|}{ Division of labor type } \\
\hline \multicolumn{5}{|l|}{ (ref: Dual-earner) } \\
\hline \multirow[t]{2}{*}{ Male-breadwinner } & -0.450 & 0.701 & $0.398^{* * *}$ & $0.692^{* * *}$ \\
\hline & $(0.468)$ & $(1.092)$ & $(0.107)$ & $(0.171)$ \\
\hline \multirow[t]{2}{*}{ Modified male-breadwinner } & 0.083 & -0.074 & $0.438^{\star \star \star}$ & $0.538^{* *}$ \\
\hline & $(0.391)$ & $(0.523)$ & $(0.098)$ & $(0.170)$ \\
\hline \multirow[t]{2}{*}{ Female-breadwinner } & -0.238 & -0.218 & 0.215 & 0.213 \\
\hline & $(0.761)$ & $(0.771)$ & $(0.217)$ & $(0.217)$ \\
\hline \multirow[t]{2}{*}{ Precarious } & -1.963 & -1.993 & $0.350^{*}$ & $0.345^{*}$ \\
\hline & $(2.567)$ & $(2.503)$ & $(0.148)$ & $(0.149)$ \\
\hline
\end{tabular}


Table A-2: (Continued)

\begin{tabular}{|c|c|c|c|c|}
\hline & \multicolumn{2}{|l|}{ First birth } & \multicolumn{2}{|c|}{ Second/higher order births } \\
\hline & Basic & Interaction & Basic & Interaction \\
\hline \multicolumn{5}{|l|}{ Period (ref: 1991-2000) } \\
\hline \multirow[t]{2}{*}{$2001-2008$} & $-1.401^{\star \star}$ & $-1.275^{*}$ & $-0.519^{\star \star *}$ & $-0.372^{*}$ \\
\hline & $(0.496)$ & $(0.524)$ & $(0.143)$ & $(0.186)$ \\
\hline \multirow[t]{2}{*}{ 2009-2017 } & $-5.733^{\star * *}$ & $-5.582^{\star \star \star}$ & $-0.494+$ & -0.289 \\
\hline & $(0.956)$ & $(0.922)$ & $(0.255)$ & $(0.275)$ \\
\hline \multicolumn{5}{|l|}{ Interactions } \\
\hline \multirow[t]{2}{*}{ Male-breadwinner * 2001-2008 } & & -1.427 & & -0.220 \\
\hline & & $(1.176)$ & & $(0.205)$ \\
\hline \multirow[t]{2}{*}{ Modified male-breadwinner * 2001-2008 } & & -0.027 & & -0.230 \\
\hline & & $(0.965)$ & & $(0.215)$ \\
\hline \multirow[t]{2}{*}{ Male-breadwinner * 2009-2017 } & & -1.593 & & $-0.529^{\star}$ \\
\hline & & $(1.248)$ & & $(0.206)$ \\
\hline \multirow[t]{2}{*}{ Modified male-breadwinner * 2009-2017 } & & 0.159 & & -0.059 \\
\hline & & $(0.656)$ & & $(0.208)$ \\
\hline \multicolumn{5}{|l|}{$\begin{array}{l}\text { Number of children (ref: zero/one for higher order } \\
\text { births) }\end{array}$} \\
\hline \multicolumn{5}{|l|}{ One } \\
\hline \multirow[t]{2}{*}{$\geqq$ Two } & & & $-2.819^{\star \star \star}$ & $-2.830^{\star \star \star}$ \\
\hline & & & $(0.089)$ & $(0.090)$ \\
\hline \multirow[t]{2}{*}{ Cohabitation } & $-2.763^{\star \star \star}$ & $-2.755^{\star \star \star}$ & $-0.665^{\star \star \star}$ & $-0.674^{\star \star \star}$ \\
\hline & $(0.791)$ & $(0.776)$ & $(0.145)$ & $(0.144)$ \\
\hline \multirow[t]{2}{*}{ Partnership duration } & $1.286^{\star \star \star}$ & $1.227^{\star \star \star}$ & 0.079 & 0.078 \\
\hline & $(0.354)$ & $(0.329)$ & $(0.119)$ & $(0.120)$ \\
\hline \multirow[t]{2}{*}{ Women's age } & $6.136^{\star \star \star}$ & $6.325^{\star \star \star}$ & $0.783^{\star \star \star}$ & $0.791^{\star \star \star}$ \\
\hline & $(1.769)$ & $(1.835)$ & $(0.162)$ & $(0.163)$ \\
\hline \multirow[t]{2}{*}{ Women's age square } & $-0.102^{\star \star \star}$ & $-0.104^{\star * \star}$ & $-0.012^{\star \star *}$ & $-0.013^{\star \star \star}$ \\
\hline & $(0.030)$ & $(0.031)$ & $(0.002)$ & $(0.002)$ \\
\hline \multirow[t]{2}{*}{ Men's age } & $2.916^{\star \star}$ & $2.912^{\star *}$ & 0.024 & 0.021 \\
\hline & $(1.066)$ & $(1.066)$ & $(0.138)$ & $(0.139)$ \\
\hline \multirow[t]{2}{*}{ Men's age square } & $-0.032^{*}$ & $-0.032^{*}$ & $-0.003^{*}$ & $-0.003^{*}$ \\
\hline & $(0.015)$ & $(0.015)$ & $(0.001)$ & $(0.001)$ \\
\hline \multicolumn{5}{|l|}{$\begin{array}{l}\text { Number of years till the next observation (ref: }<1 \\
\text { year) }\end{array}$} \\
\hline \multirow[t]{2}{*}{$1-2 y r$} & 0.128 & 0.116 & $0.128^{*}$ & $0.126+$ \\
\hline & $(0.137)$ & $(0.141)$ & $(0.065)$ & $(0.065)$ \\
\hline \multirow[t]{2}{*}{$2-3 y r$} & $1.235^{\star *}$ & $1.236^{* *}$ & $2.463^{\star * *}$ & $2.468^{* \star *}$ \\
\hline & $(0.441)$ & $(0.457)$ & $(0.108)$ & $(0.108)$ \\
\hline \multirow[t]{2}{*}{$3 y r^{+}$} & $4.369^{\star \star \star}$ & $4.432^{* \star \star}$ & $1.540^{\star \star \star}$ & $1.533^{\star \star *}$ \\
\hline & $(0.918)$ & $(0.940)$ & $(0.191)$ & $(0.192)$ \\
\hline Couples & 712 & & 2,348 & \\
\hline Couple-year observations & 2,714 & & 15,649 & \\
\hline
\end{tabular}

Note: Exclusions are made based on whether the couple expects to have a child within the next six months to ensure enough number of cases to conduct separate analyses by parity order. Standard errors are in parentheses. ${ }^{\star} p<.05^{\star \star} p<.01^{\star \star \star} p<.001$. 
Zhou \& Kan: Changing dynamics between the gender division of labor and fertility in Great Britain 